Campbell University School of Law

Scholarly Repository @ Campbell University School of Law

\title{
The Missing Piece of the Puzzle: Perspectives on the Wage Priority in Bankruptcy
}

C. Scott Pryor

Campbell University School of Law, pryors@campbell.edu

Follow this and additional works at: https://scholarship.law.campbell.edu/fac_sw

\section{Recommended Citation}

C. Scott Pryor, The Missing Piece of the Puzzle: Perspectives on the Wage Priority in Bankruptcy, 16 Am. Bankr. Inst. L. Rev. 121 (2008).

Available at: https://scholarship.law.campbell.edu/fac_sw/115

This Article is brought to you for free and open access by the Faculty Scholarship at Scholarly Repository @ Campbell University School of Law. It has been accepted for inclusion in Scholarly Works by an authorized administrator of Scholarly Repository @ Campbell University School of Law. 


\section{THE MISSING PIECE OF THE PUZZLE: PERSPECTIVES ON THE WAGE PRIORITY IN BANKRUPTCY}

\section{SCOTT PRYOR*}

In its 2006 6-3 decision in Howard Delivery Service, Inc. v. Zurich Am. Ins. Co., the Supreme Court declined to extend the bankruptcy priority for employee benefits to premiums due for workers' compensation insurance. Neither the majority nor the dissent looked back further than decisions in 1959 and 1968, both of which had held with the same 6-3 vote that employee benefits should not be accorded priority as wages under the Bankruptcy Act of 1898. However, the wage priority had an intriguing history and represents a distinctive normative policy with respect to wage earners and their families, a history and policy ignored by the Court in 2006.

The wage priority first appeared in the Bankruptcy Act of 1841 where it represented a political gambit by the recently-formed Whig party to garner the support of socially active Christian evangelicals. The rise of industrialism and the market economy following the War of 1812 had forever changed the agrarianartisan small community ideal of the Founding Era. Concurrently with the continuing Second Great Awakening and evangelical revivalism, the market revolution drew the attention of commercial writers who, drawing on widespread biblical literacy, framed the issues of business success and failure in explicitly moral terms. The recently formed Whig party made a bankruptcy law part of a platform in 1840 that helped propel them to brief political success.

The wage priority lived on in the Bankruptcy Acts of 1867 and 1898 and the Bankruptcy Code of 1978 where it lost its religious moorings but retained a moral foundation: to protect those most at risk from a political economy that was ever more individualistic and market driven. Courts, including the Supreme Court, regularly cited this policy until 2006 when it disappeared without explanation.

\section{INTRODUCTION}

Debate about priorities among creditors has extended for over twenty years and, while slowing, hasn't ended in a consensus. Most of the focus of this debate has been on secured credit. ${ }^{1}$ But secured credit persists notwithstanding various academic criticisms about it. ${ }^{2}$

\footnotetext{
* Professor of Law, Regent University School of Law. J.D. 1980, University of Wisconsin Law School. M.A. 1997, Reformed Theological Seminary. Thanks are due to many including David Epstein and John C. McCoid, II for their comments on an earlier draft and David Skeel and Craig Stern for their remarks on a later version. The research and editorial assistance of Bill Magee, Bethany Flitton, and Michael Butler was a great help. I must also thank Regent Law School and the American Center for Law and Justice for their financial support for this project. Any errors and misstatements are, of course, my own.

${ }^{1}$ For a selection of articles arguing against full priority for secured credit see Lynn M. LoPucki, The Unsecured Creditor's Bargain, 80 VA. L. REV. 1887 (1994) (arguing involuntary creditors should have
} 
The interesting questions about priority thus shift to the variegated world of unsecured credit. And the battlefield for such priority fights today is in the Bankruptcy Code. If secured creditors can take all the pie for which they've contracted, do the remaining unsecured creditors share the pie equally? Or, are some unsecured creditors more equal than others? The answer to the latter questions is of course yes. Beginning with section 5 of the Bankruptcy Act of 1841 Congress determined that one sort of unsecured creditors-employees-have statutory priority over other unsecured creditors in the event of bankruptcy. ${ }^{3}$

Not much has been written about the history or justification for this statutory priority. ${ }^{4}$ Granting that secured creditors will enjoy the fruits of their consensual interests in a debtor's property, why should any creditor who has not contracted for priority nonetheless obtain it? Could the wage priority be efficient? $\mathrm{Or}$ is this priority better explained by principles outside the sphere of the market? Part I of this Article summarizes the legal history of the wage priority in bankruptcy beginning with the Bankruptcy Act of 1841. With barely an acknowledgement of priority among creditors in 1800 , we will see a process of ever-increasing legislative growth in the protection of employees in America's bankruptcy law. We

priority over secured creditors); Elizabeth Warren, Making Policy With Imperfect Information: The Article 9 Full Priority Debates, 82 CORNELL L. REV. 1373 (1997) (discussing expansion of priority for commercial lenders); Steven L. Harris \& Charles W. Mooney, Jr., Measuring the Social Costs and Benefits and Identifying the Victims of Subordinating Security Interests in Bankruptcy, 82 CORNELL L. REV. 1349 (1997) (considering costs and benefits of subordinating secured creditors to unsecured or tort claimants in bankruptcy).

${ }^{2}$ For some articles supporting contractual secured priority see Jeffrey S. Turner, The Broad Scope of Revised Article 9 Is Justified, 50 CONSUMER FIN. L.Q. REP. 328 (1996); Steven L. Harris \& Charles W. Mooney, Jr., A Property-Based Theory of Security Interests: Taking Debtors' Choices Seriously, 80 VA. L. REV. 2021, 2024 (1994) (pointing out positive aspects of engaging in secured transactions); Lawrence A. Weiss, Bankruptcy Resolution: Direct Costs and Violation of Priority of Claims, 27 J. FIN. ECON. 285 (1990). For others commenting on the place of secured credit in today's political economy see C. Scott Pryor, How Revised Article 9 Will Turn the Trustee's Strong Arm Into a Weak Finger: A Potpourri of Cases, 9 AMER. BANKR. INST. L. REV. 229 (2001); Heather Lauren Hughes, Creditors' Imagined Communities and the Unfettered Expansion of Secured Lending, 83 DENV. U. L. REV. 425, 434 (2005) ("In the midst of this debate [about the priority of secured credit], the 1999 revisions to Article 9 only expand the reach of full priority secured credit.").

${ }^{3}$ Bankruptcy Act of 1800, ch. 19, 2 Stat. 19, § 5, repealed by Act of Dec. 19, 1803, ch. 6, 2 Stat. 248

\begin{abstract}
[A]ll creditors coming in and proving their debts ... shall be entitled to share in the bankrupt's property and effect, pro rata, without any priority or preference whatsoever, except ... [that] any person who shall have performed any labor as an operative in the service of any bankrupt shall be entitled to receive the full amount of the wages due to him for such labor, not exceeding twenty-five dollars . . . .
\end{abstract}

\footnotetext{
${ }^{4}$ For some exceptions see BRUCE G. CARRUTHERS \& TERENCE C. HALlidAY, Rescuing Business: ThE MAKING OF CORPORATE BANKRUPTCY LAW IN ENGLAND AND THE UNITED STATES (Clarendon Press 1998); Paul G. Kauper, Insolvency Statutes Preferring Wages Due Employees, 30 MICH. L. REV. 504, 507 08 (1931) (citing five reasons for wage priority statutes: wage-earner dependency, inequality in bargaining power, limited investigatory ability, limited financial resources, and workers' "interest" in product produced); Daniel Keating, The Fruits of Labor: Worker Priorities in Bankruptcy, 35 ARIZ. L. REV. 905,926 (1993) (addressing priority issues of employee wages in employer's bankruptcy).
} 
will also note the policies surrounding the wage priority articulated by the courts as they considered cases at its edge.

Part II will turn to the Supreme Court's most recent foray into statutory priorities, Howard Delivery Service, Inc. v. Zurich Am. Ins. Co. The Court in Howard Delivery concluded that the statutory priority afforded to employee benefits did not extend to unpaid premiums for workers' compensation insurance. ${ }^{6}$ The Court's specific holding doesn't tell the entire story. During the course of its analysis the majority cited several long-standing bankruptcy policies in support of its conclusion. Yet the Court passed over without mention one other policy that had informed its analysis in two decisions under the 1898 Bankruptcy Act: ${ }^{7}$ protection of wage earners and their families.

Thus, in Part III I consider three perspectives on the justification of the wage priority. Market failure contrasting with rational autonomy are the first two. The third perspective-the normative-considers the morality of a wage priority. This Part also examines the religious, cultural, and political matrix of the 1841 Act, focusing on ante-bellum American evangelicals and the rising Whig party. I will argue that religious and political confluences on public morality played a significant role in the creation of the wage priority. Reference to America's religious history is not a mere add-on. Rather, such a perspective can inform an originalist vision of statutory interpretation and provide significant clues for those who are guided by the text. ${ }^{8}$

\section{HISTORY OF THE WAGE PRIORITY IN BANKRUPTCY}

\section{A. The Early Years-The Bankruptcy Act of 1841 (with Glances at the Acts of 1800 and 1867)}

The short-lived ${ }^{9}$ Bankruptcy Act of 1800 was a creditor remedy to deal with absconding or otherwise recalcitrant merchants. ${ }^{10}$ Interestingly, however, this first stab at bankruptcy legislation effected a prospective elimination of priority in

\footnotetext{
${ }^{5} 126$ S. Ct. 2105 (2006).

${ }^{6}$ See infra text accompanying notes 121-132 for a discussion of Bankruptcy Code section 507(a)(4) (wage priority statute) and section 507(a)(5) (employee benefit priority provision).

${ }^{7}$ See infra text accompanying notes $135-138$.

${ }^{8}$ The utility to a purposeful approach to statutory interpretation goes without saying, at least for those who share the purpose of assisting families to survive in the individualistic marketplace.

${ }^{9}$ Passed by the House on April 4, 1800; repealed by the House on December 19, 1803. See Richard E. Coulson, Consumer Abuse of Bankruptcy: An Evolving Philosophy of Debtor Qualification for Bankruptcy Discharge, 62 ALB. L. REV. 467, 473 (1998) (stating Bankruptcy Act of 1800 Act was repealed in 1803); John E. Matejkovic \& Keith Rucinski, Bankruptcy "Reform:" The 21st Century's Debtors' Prison, 12 AM. BANKR. INST. L. REV. 473, 479 (2004) (noting brief duration of 1800 Act).

${ }^{10}$ See Charles Jordan Tabb, The History of the Bankruptcy Laws in the United States, 3 AM. BANKR. INST. L. REV. 5, 6-12 (1995) (describing English antecedents, occasion for enactment, and reasons for short life of the 1800 Act). See generally BRUCE H. MANN, REPUBLIC OF DEBTORS 8-10 (2002) (discussing incidents of debtor-creditor relationship in Colonial and early post-colonial America); Coulson, supra note 9, at 473 (asserting Bankruptcy Act of 1800 was for creditors seeking remedy from bankers and merchants).
} 
distribution for liens (consensual, statutory, or judicial), ${ }^{11}$ although liens existing as of the date of the Act were not affected. ${ }^{12}$ The 1800 Act provided only one priority-for administrative expenses of the assignee chosen by the creditors ${ }^{13}$ after which net proceeds were to be paid to secured and unsecured creditors pro rata. $^{14}$

${ }^{11}$ See Bankruptcy Act of 1800 , supra note $3, \S 31$

[I]n the distribution of the bankrupt's effect, there shall be paid to every of the creditors a portion-rate, according to the amount of their respective debts, so that every creditor having security for his debt by judgment, statute, recognizance, or specialty, or having an attachment under any of the laws of the individual states, or of the United States, on the estate of such bankrupt . . . shall not be relieved upon any such judgment, statute, recognizance, specialty, or attachment, for more than a rateable [sic] part of his debt, with the other creditors of the bankrupt.

Harrison v. Sterry, 9 U.S. 289, 301 (1809) ("By the bankrupt law of the United States, their [the attaching creditors'] priority, as to the funds of the bankrupt, is lost. They can only claim a dividend with other creditors."); Harmon v. Jamesson, 11 F. Cas. 555 (C.C.D.C. 1806) (No. 6079) (avoiding attachment lien and requiring payment of attached funds assignees for distribution to creditors).

${ }^{12}$ See Bankruptcy Act of 1800 , supra note $9, \S 63$ ("[N]othing contained in this act, shall be taken, or construed to invalidate, or impair any lien existing at the date of this act, upon the lands or chattels of any person who may have become a bankrupt.").

${ }^{13}$ See id.

[T] he said assignee or assignees [chosen by the creditors] shall be allowed and retain all such sum and sums of money, as they shall have paid or expended in suing out and prosecuting the commission, and all other just allowances on account of, or by reason or means of their being assignee or assignees ....

${ }^{14}$ Id.

[T] he said commissioners shall order such part of the nett [sic] produce of the said bankrupt's estate . . . to be forthwith divided among such of the bankrupt's creditors as have duly proved their debts ... in proportion to their several and respective debts ....

Notwithstanding the initial emphasis of the Bankruptcy Act of 1800 on equality of all creditors, section 62 provided for one set of priority claimants whose identity should come as no surprise:

[N]othing contained in this law shall, in any manner, effect the right or preference to prior satisfaction of debts due to the United States as secured or provided by any law heretofore passed, nor shall be construed to lessen or impair any right to, or security for, money due to the United States or to any of them.

Section 62 of the Bankruptcy Act of 1800 was almost certainly intended to preserve the federal priority statute enacted only three years earlier by the Fourth Congress, which provided the United States government "shall be paid first" for all obligations to the federal government. See Act of Mar. 3, 1797, ch. 20, § 5, 1 Stat. 515 (1797) (current version at 31 U.S.C. \$ 3713(a) (2000)); Harrison, 9 U.S. at 299-300 (holding section 62 of Bankruptcy Act of 1800 specifically preserved rights contained in federal priority statute). 
After the repeal of the 1800 Act, Congress left its bankruptcy power unused until another business depression beginning in $1837 .{ }^{15}$ The Bankruptcy Act of 1841 more closely resembles current bankruptcy law than the $1800 \mathrm{Act}^{16}$

Relief under the 1841 Act was explicitly voluntary ${ }^{17}$ and with certain exceptions was available to all residents (not merely merchants) of the United States and its territories. ${ }^{18}$ The 1841 Act expressly preserved liens and security that were otherwise valid under state law. ${ }^{19}$ Pro rata distributions were the norm, ${ }^{20}$ but there

${ }^{15}$ See Tabb, supra note 10, at 16 ("[T] over the Democrats in the 1840 election, turned the tide. In a very close vote, the Bankruptcy Act of 1841 was passed."); see also Harvey R. Miller \& Shai Y. Waisman, Does Chapter II Reorganization Remain a Viable Option for Distressed Businesses for the Twenty-First Century?, 78 AM. BANKR. L. J. 153, 159 (2004) (noting Bankruptcy Act of 1841 was "in response to the panic of 1837"); Ann Haberfelde, Note, $A$ Reexamination of the Non-Dischargeability of Criminal Restitutive Obligations in Chapter 13 Bankruptcies, 43 HASTINGS L. J. 1517, 1526 n.55 (1992) (referencing "panic of 1837" as "main reason" for enactment of Bankruptcy Act of 1841).

${ }^{16}$ See Charles Warren, Bankruptcy IN UNITed STATes History 52 (1935) ("It was the great Panic of 1837 and the depression of the succeeding years that revived the pressure for a bankrupt law ...."); Tabb, supra note 10, at 18 ("The 1841 Act, with its marriage of the concepts of 'bankruptcy' and 'insolvency,' could be called the first modern bankruptcy law."). See generally Bankruptcy Act of 1841, § 5 (advocating preferential distribution of estate).

${ }_{17}$ See MANN, supra note 10, at 228-39 (documenting cooperative use of Bankruptcy Act of 1800 to achieve voluntary bankruptcy); John C. McCoid, II, The Origins of Voluntary Bankruptcy, 5 BANKR. DEV. J. 361, 361-62 (1988) (discussing origins of voluntary petition in bankruptcy).

${ }^{18}$ See Bankruptcy Act of 1841 , ch. 9,5 Stat. 440, § 1, repealed by Act of Mar. 3, 1843, ch. 82, 5 Stat. 614

\begin{abstract}
All persons whatsoever, residing in any State, District or Territory of the United States, owing debts, which shall not have been created in consequence of a defalcation as a public officer; or as executor, administrator, guardian or trustee, or while acting in any other fiduciary capacity, who shall ... apply to the proper court . . . shall be deemed bankrupts within the purview of this act ....
\end{abstract}

The same section went on to reinstate the ability of creditors to seek involuntary bankruptcy with respect to merchants and other persons engaging in business. See id.; see also Karen Gross et al., Ladies in Red: Learning From America's First Female Bankrupts, 40 AM. J. LEGAL HIST. 1, 10 (1996) ("[T]he Bankruptcy Act of 1841 permitted both voluntary and involuntary filings, and debtors were not limited to merchants and traders."); John E. Matejkovic \& Keith Rucinski, Bankruptcy "Reform": The 2Ist Century's Debtor's Prison, 12 AM. BANKR. INST. L. REV. 473, 479 (2004) (noting precedence of 1841 Act in permitting both voluntary and involuntary bankruptcies).

${ }^{19}$ See Bankruptcy Act of 1841 , supra note $18, \S 2$ ("[N]othing in this act contained shall be construed to annul, destroy, or impair ... any liens, mortgages, or other securities on property, real or personal, which may be valid by the laws of the States respectively ....").

${ }^{20}$ See Bankruptcy Act of 1841 , supra note 18, $\$$ : (" (A]ll creditors coming in and proving their debts ... shall be entitled to share in the bankrupt's property and effects, pro rata, without any priority or preference whatsoever ...."). The failure of the 1841 Act to make specific provision for priority distributions to secured creditors does not mean that Twenty-Seventh Congress, dominated by Whigs, opposed commercial interests. Instead, the District or Circuit Courts under the 1841 Act had plenary (and non-appealable) jurisdiction to decide the rights of secured creditors by applying state law. See, e.g., Waller's Lessee v. Best, 44 U.S. 111,120 (1845) (holding state law governed timing of creation of execution liens); Ex parte Christy, 44 U.S. 292, 319 (1845) (holding delays accompanying piecemeal consideration of secured claims in multiple state courts could be "avoided[,] by bringing the whole matters in controversy between all the mortgagees before the District Court of Circuit Court, making them all parties to the summary proceedings in equity, and thus enabling the court to marshal the rights, and priorities, and claims, of all the parties ... .); see also Adam J. Levitin, Toward a Federal Common Law of Bankruptcy: Judicial Lawmaking In a 
were now three categories of priority among creditors: debts to the United States, debts to sureties of federal obligations, and wages due to "operatives" (employees). ${ }^{21}$

Insertion of a priority for unpaid wages reflected the effects of increasing industrialization. In his ground-breaking book THE MARKET REVOLUTION, Charles Sellers begins a narrative with America's Colonial society comprised of selfcontained, rural, agrarian communities and urban artisans. ${ }^{22}$ Domesticity and community solidarity characterized this Jeffersonian idyll. Viewed in prospect, neither bankruptcy nor a wage priority were necessary. Credit would hardly exist outside the small class of merchants. ${ }^{23}$ And, given a pre-industrial economy, most employees would have been apprentices or farm hands from the community whose interests would be protected by close personal relationships. Beginning in the

Statutory Regime, 80 AM. BANKR. L.J. 1, 6 (2006) ("The Bankruptcy Act of 1841 provided that district courts' jurisdiction in bankruptcy was 'to be exercised summarily, in the nature of summary proceedings in equity."').

${ }^{21}$ Bankruptcy Act of 1841 , supra note 18 , section 5 continues to read as follows:

[E]xcept only for debts due by such bankruptcy to the United States, and for all debts due by him to persons who, by the laws of the United States, have a preference, in consequence of having paid moneys as his sureties, which shall be first paid out of the assets; and any person who shall have performed any labor as an operative in the service of any bankrupt shall be entitled to receive the full amount of the wages due to him for such labor, not exceeding twenty-five dollars ....

Congress may have intended the bankruptcy priority for the United States to capture any obligations or assets to which the general federal priority statute didn't attach. See supra note 14 . Or maybe Congress was simply erring on the side of assurance of payment. Priority for sureties of federal obligations should probably be seen as a tool of stimulating international trade and enhancing collection of customs duties. See Richard H.W. Maloy, The "Priority Statute"-The United States' "Ace-in-the-Hole," 39 J. MARSHALL L. REV. 1205, 1209 (2006) (highlighting role of priority statute in 17th century American commerce); Barbara K. Morgan, Should the Sovereign Be Paid First? A Comparative International Analysis of the Priority for Tax Claims, 74 AM. BANKR. L.J. 461, 463 (2000) ("[I]n 1789, at a time when the revenues of the United States derived primarily from customs duties and whiskey taxes, one of Congress's first legislative acts was to grant the new federal government the right to be paid first when a person indebted to the United States became insolvent.").

${ }^{22}$ See, e.g., Daniel Walker Howe, What Hath God Wrought: THE Transformation of AMERICA, 1815-1848 5 (2007) (interpreting early nineteenth-century America under rubric of "communications revolution"); see ChARLES SELLERS, THE MARKET REVOLUTION: JACKSONIAN AMERICA, 1815-1846, at 333 (1991). Others have characterized this period differently. Yet Sellers and Howe agree that this was a revolutionary period in American history, and Howe certainly credits the fact of the enormous growth of the market economy. See HowE, supra at 542. They disagree only on this period's leading characteristic. For my purposes, the perspective of the market revolution is the more useful for analyzing the history and policy of the Bankruptcy Act of 1841 .

${ }^{23}$ See Craig T. Friend, Merchants and Markethouses: Reflections on Moral Economy in Early Kentucky, 17 J. EARLY REPUB. 553, 558 (1997) ("In premarket moral economies like those of colonial America, the local merchant acted as an economic patriarch over a 'household' whose members became bound to the business through networks of credit and barter."); Gregory Nobles, The Rise of Merchants in Rural Market Towns: A Case Study of Eighteenth-Century Northampton, Massachusetts, 24 J. SOC. HIST. 5, 5 (1990) (portraying merchants as catalysts of social transformation in 17th century rural New England by connecting consumers with credit ). But see MANN, supra note 10, at 131-32 (discussing effects of massive agricultural indebtedness of Virginia Tidewater plantation owners). 
second decade of the nineteenth century, however, Sellers describes a new market economy driven by "mobility, efficiency, individual self-exertion, specialization, productivity, expanding consumption, and a way of life that disrupted communities, uprooted relationships, and commodified family connections." ${ }^{24}$ Thus, "[t]he practical issue that faced most American workers [in ante-bellum America] was not the acceptance or rejection of wage labor but acceptance on what terms and with what qualifications."

The 1841 Act both capped the amount of the wage priority at twenty-five dollars ${ }^{26}$ and limited the period immediately prior to bankruptcy for which the unpaid employee could assert it to six months. ${ }^{27}$ The few reported decisions under the 1841 Act dealing with wage priority construed "operative" broadly, ${ }^{28}$ but denied

24 Mark A. NOll, God ANd Mammon: Protestants, MONEY, AND THE MARKeT, 1790-1860 3, 16 (Mark A. Noll ed., Oxford University Press 2002).

${ }^{25}$ R. Laurence MoOre, Selling God: American Religion in the Marketplace of Culture 76 (1994).

${ }^{26}$ See S. Morgan Friedman, The Inflation Calculator, http://www.westegg.com/inflation/ (last visited February 14, 2008). There are several means by which to estimate the current worth of twenty-five dollars in 1841. A straight inflation formula equates $\$ 25$ in 1840 to $\$ 481$ in 2007 . Insert $\$ 25$ in "amount" and "1840" as the year to see how much $\$ 25$ in 1840 would equate to in 2007 .

${ }^{27}$ See Bankruptcy Act of 1841 , supra note 18 , at $\$ 5$ ("Provided, that such labor shall have been performed within six months next before the bankruptcy of his employer ...." The six-month look-back is the same as under the current Bankruptcy Code) (emphasis added); 11 U.S.C. \$ 507(a)(4) (2006) [hereinafter Bankruptcy Code §] ("(a) The following expenses and claims have priority in the following order ... (4) Fourth, allowed unsecured claims, but only to the extent of $\$ 10,950$ for each individual or corporation, as the case may be, earned within 180 days before the date of the filing of the petition or the date of the cessation of the debtor's business, whichever occurs first . . . ."); see also Daniel Keating, The Fruits of Labor: Worker Priorities in Bankruptcy, 35 ARIZ. L. REV. 905, 912 (1993) ("[The] 180-day period under $\$ 507(a)(4)$ will be measured by the debtor's bankruptcy filing. However, the language of [this] provisions is clear that if the debtor ceases doing business prior to filing bankruptcy, the relevant priority period will be measured from the point immediately preceding the cessation of business.").

${ }^{28}$ See Ex parte Steiner, 22 F. Cas. 1234 (C.C.E.D. Pa. 1842) (holding claim of apprentice against master for extra pay for extra work qualified as priority claim of "operative" notwithstanding possible unenforceability of claim under state law). A year later the Supreme Judicial Court of Massachusetts considered a virtually identical provision affording priority to "operatives" under Massachusetts law and wrote:

\footnotetext{
We are not aware, that this clause has received any judicial construction, and the word "operative," without more qualification than this clause contains, is not definite enough to enable us to lay down any precise general rule. Probably the primary thought, which legislators had in mind, was the wages due to men and women working in manufactories, who usually receive their pay weekly or monthly. But certainly, it is not limited to those working for manufacturers, or mechanics, or to persons working in factories or workshops. Whether it shall extend to farm-laborers, to house servants, to persons working singly or in gangs, in woods, or on marshes, or under contractors on public works, at a distance from the home both of the employer and the laborer, are all open questions ....
}

See Thayer v. Mann, 56 Mass. 371, 373 (Mass. 1848); see also Ex parte Rockett (In re Taylor), $20 \mathrm{~F}$. Cas. 1070 (D. Mass. 1876) ("'[T]hat any person who shall have performed any labor as an operative in the service of the insolvent' ... I think it comes fairly within the true meaning of the statute, reasonably and liberally construed, and that without departing in the least from the ordinary meaning of the words employed." (quoting Thayer, 56 Mass. at 373)) 
that one could be subrogated to wage priority status. ${ }^{29}$ Although no federal case analyzed the policy of the wage priority under the 1841 Act, a Massachusetts court held with respect to that state's wage priority statute that "[w]e think the policy of the statue was to secure to a class of very needy and efficient laborers, who are very dependent and meritorious but who have little means of knowing the credit of their employers, the small amount due them for very recent service. ${ }^{130}$ The wage priority reflected an increasing consciousness of the situation in which the growing class of wage earners found themselves. Recognition of the changing nature of employment in the new market economy as well a morally-grounded sense of paternalism were at work.

The 1841 Bankruptcy Act was of even shorter duration than its 1800 predecessor-thirteen months compared to forty-four months. It too was repealed with better economic times ${ }^{31}$ and the bankruptcy clause lay dormant until 1867 . But "[a]fter the Panic of 1857 and the financial cataclysm caused by the American Civil War, overwhelming pressure for another federal bankruptcy law led to the enactment of the Bankruptcy Act of 1867."132

The 1867 Act opened the door to all residents of the United States ${ }^{33}$ and represented another step of detailed specification toward the current Bankruptcy Code. The validity of security was expressly acknowledged. ${ }^{34}$ The same section

\footnotetext{
${ }^{29}$ See In re Paulson, 19 F. Cas. 4, 5 (S.D.N.Y. 1842) (No. 10,849) (holding claim of one who had lent bankrupt money for payment of operatives was not entitled to priority under section 5 of the 1841 Bankruptcy Act); see also In re Pac. Oil \& Meal Co., 24 F. Supp. 767, 771 (S.D. Cal. 1938) (emphasizing that "any right to priority in bankruptcy should be clearly authorized by the [Bankrutpcy] Act and established by the evidence... This process ought not to be extended beyond the clear requirements of the controlling statutes"). See generally In re Estey, 6 F. Supp. 570 (S.D.N.Y. 1934) (discussing Congress' special protection of class of wage earners and distinguishing between salary and wages).

${ }^{30}$ Thayer, 56 Mass. at 374

${ }^{31}$ See Tabb, supra note 10, at 18 ("With immediate goal of relieving the plight of the mass of insolvent debts accomplished, and with little continuing political capital to be gained from the law, the 1841 act was repealed in early 1843 after little more than a year of operation."); see also Richard E. Coulson, Substantial Abuse of Bankruptcy Code Section 707(B): An Evolving Philosophy of Debtor Need, 52 CoNSUMER Fin. L.Q. REP. 261. 263 (1998) ("The Bankruptcy Act of 1841 was passed August 19, 1841 but did not become effective until February 1, 1842. It lasted a little more than one year before being repealed on March 1843."); Richard E. Flint, Bankruptcy Policy: Toward a Moral Justification for Financial Rehabilitation of the Consumer Debtor, 48 WASH. \& LEE L. REV. 515, 546-547 (1991)
}

[T]he statute's use of federal exemptions without any homestead protection rekindled fear in the agricultural states regarding the potential loss of land by debtors. On the other hand, the statute's seemingly overall pro-debtor bent . . . led to creditor dissatisfaction. Creditors asserted that the 1841 Act was not a bankruptcy statute but merely an insolvency statute, and, thus, its enactment was beyond the power of Congress. It was repealed soon thereafter by the same Congress that enacted it.

${ }^{32}$ See Tabb, supra note 10 , at 19.

${ }^{33}$ See Bankruptcy Act of 1867 , ch. 176, 14 Stat. 517, $\$ 11$ (repealed by Act of June 7, 1878, ch. 160, 20 Stat. 99) (allowing "any person residing within the jurisdiction of the United States," with debts in excess of three hundred dollars, to file bankruptcy petition).

${ }^{34}$ See id., at $\$ 20$. 
also for the first time authorized the assignee to sell encumbered property for the benefit of creditors, ${ }^{35}$ who were to enjoy an equality of distribution as of first importance. ${ }^{36}$ The 1867 Act clarified the distribution rights of secured creditors by expressly allowing them to share in dividends for the difference between the value of the collateral and the debt. ${ }^{37}$

Administrative expenses and, for the first time, compensation of the assignee had first priority in distribution. ${ }^{38}$ Section 27 of the 1867 Act provided that all unsecured claims were to be paid pro rata with the exception of employees whose priority was increased to fifty dollars. ${ }^{39}$ The next section of the Act, however, provided for five levels of priority:

\begin{abstract}
When a creditor has a mortgage or pledge of real or personal property of the bankrupt, or a lien thereon for securing the payment of a debt owing to him from the bankrupt, he shall be admitted as a creditor only for the balance of the debt after deducting the value of such property....
\end{abstract}

In re McConnell, 15 F. Cas. 1297, 1298 (C.C.D.N.J. 1874) (No. 8,712) ("[I]t is undoubtedly the duty of the court to recognize and enforce any lien which [the creditor] may have by virtue of state law."); see also Bavely v. U.S Internal Revenue Serv. (In re Terwilliger's Catering Plus, Inc.), 911 F.2d 1168, 1175 (6th Cir. 1990) (stating certain secured interests were protected under Bankruptcy Act of 1867); cf. In re Henry, 266 B.R. 457, 474 n.18 (Bankr. C.D. Cal. 2001) (noting Bankruptcy Act of 1867 disallowed certain claims for secured debts).

${ }^{35}$ See Bankruptcy Act of 1867 , supra note $33, \S 14$ ("The assignee shall have the authority, under the order and direction of the court ... to sell the same [encumbered property] subject to such mortgage, lien or other encumbrances."); Glenny v. Langdon, 98 U.S. 20, 25 (1878) (explaining that Bankruptcy Act of 1867 conferred on assignee power to sell property, subject to encumbrances); Yeatman v. New Orleans Sav. Inst., 95 U.S. 764, 767 (1877) (explaining under Bankruptcy Act of 1867, section 14, "[a]mong the rights which vest at once in the assignee by virtue of the adjudication in bankruptcy, and of his appointment as such assignee, is the right to redeem the property or estate of the bankrupt").

${ }^{36}$ See Bankruptcy Act of 1867, supra note 33, § 14; Bailey v. Glover, 88 U.S. (21 Wall.) 342, 346 (1874) ("It is obviously one of the purposes of the Bankrupt law, that there should be a speedy disposition of the bankrupt's assets ... [t]his is only second in importance to securing equality of distribution."); McCan v. Conery, 12 F. 315,319 (C.C.E.D. La. 1882) (applying Bailey's purpose of Bankruptcy Act of 1867 to statutes of limitation and deadlines).

${ }^{37}$ See Bankruptcy Act of 1867 , supra note 33, § 20; In re McConnell, 15 F. Cas. at 1298 (holding unsecured creditors get dividend only after landlord who enjoyed statutory lien under state law was paid). Of course, the right of secured creditors to realize on their collateral and share in the estate for any shortfall would have been recognized under the 1800 Act. See Harrison v. Sterry, 9 U.S. (5 Cranch) 289, 302 (1809) (stating law could not affect preference rights of secured creditor); $E x$ parte Christy, 44 U.S. (3 How.) 292, 319 (1845) (holding creditors secured by mortgage have foreclosure right against collateral property).

${ }^{38}$ See Bankruptcy Act of 1867 , supra note 33, $\$ 17$ ("[T] he assignee shall . . be allowed, and may retain out of money in his hands, all the necessary disbursements made by him in the discharge of his duty, and a reasonable compensation for his services, in the discretion of the court."); In re Noyes, 18 F. Cas. 465,466 (C.C.D. Mich. 1872) (No. 10,371) (interpreting language of section seventeen to require assignee apply to court for administrative expenses); In re Dean, 7 F. Cas. 286, 291 (C.C.D. Ky. 1868) (No. 3,699)

[I]t is too plain for discussion, that this provision [of the Bankruptcy Act of 1867] means, that the assignee is to be allowed both his disbursements, and, at all events, a reasonable compensation for his services in all cases, and that he may retain the sum allowed out of money in his hands, if he has any.

${ }^{39}$ See Bankruptcy Act of 1867 , supra note 33, § 27 
1. Administrative expenses;

2. Debts, including taxes, due to the United States;

3. Debts, including taxes, due to the state in which the bankruptcy case was pending;

4. Wage claims; and

5. Any other priority created by a law of the United States. ${ }^{40}$

[A]ll creditors whose debts are duly proved and allowed shall be entitled to share in the bankrupt's property and estate pro rata, without any priority or preference whatever except that wages due from him to any operative, or clerk, or house servant, to an amount not exceeding fifty dollars, for labor performed within six months next preceding the adjudication of bankruptcy, shall be entitled to priority, and shall be first paid in full ....

U.S. v. Herron, 87 U.S. (20 Wall.) 251, 259 (1873) (referring to Bankruptcy Act of 1867, and remarking "preferences are forbidden in order that equal distribution may be effected"); In re Erwin, 8 F. Cas. 779, 780 (C.C.D. Ga. 1870) (No. 4,524) (holding section 27 affords no priority to judgment creditors).

${ }^{40}$ Bankruptcy Act of 1867 , supra note $33, \S 28$

[A] third meeting of creditors shall then be called by the court, and a final dividend then declared ... . Preparatory to the final dividend, the assignee shall submit his account to the court and file the same, and give notice to the creditors of such filing ... . The court shall thereupon order a dividend of the estate and effects, or of such part thereof as it sees fit, among such of the creditors as have proved their claims, in proportion to the respective amount of their said debts . . . In the order for a dividend, under this section, the following claims shall be entitled to priority or preference, and to be first paid in full in the following order:

First. The fees, costs, and expenses of suits, and the several proceedings in bankruptcy under this act, and for the custody of property, as herein provided.

Second. All debts due to the United States, and all taxes and assessments under the laws thereof.

Third. All debts due to the State in which the proceedings in bankruptcy are pending, and all taxes and assessments made under the laws of such State.

Fourth. Wages due to any operative, clerk, or house servant, to an amount not exceeding fifty dollars, for labor performed within six months next preceding the first publication of the notice of proceedings in bankruptcy.

Fifth. All debts due to any persons who, by the laws of the United States, are or may be entitled to a priority or preference, in like manner as if this act had not been passed: Always provided, That nothing contained in this act shall interfere with the assessment and collection of taxes by the authority of the United States or any State.

The significance of the final proviso can be debated. The editors of the fourteenth edition of Colliers on Bankruptcy suggest that it "apparently lifted such debts into a position prior even to costs of administration, notwithstanding their otherwise expressly subordinate character." 3A COLLIER ON BANKRUPTCY, II 64.01, at 2047 (James William Moore, et al. eds., 14th ed. 1967). Alternatively, it could simply be understood to preserve lien rights and the ability of these units of civil government to collect from the debtor or the debtor's property after bankruptcy. See ORLANDO F. BUMP, BUMP ON BANKRUPTCY 241-42 (10th ed. 1877). 
Regardless of the relationship between sections 27 and 28 of the 1867 Act, unpaid wages continued to enjoy a limited but substantial priority. The wage priority had, however, fallen one place and was now behind certain state claims over which it would have enjoyed priority under the 1841 Act. Judicial construction of section 28 was generous. A father claiming wages on behalf of his minor son ${ }^{41}$ and a temporary accountant ${ }^{42}$ were both afforded priority. However, in 1878 the District Court drew the line: there would be no priority for an amount due for services to be rendered under an employment contract, which the bankrupt had breached when it went out of business. ${ }^{43}$ While the Register in bankruptcy had relied on the family-protection policy of the law ${ }^{44}$ to allow the employee a priority for future wages he would have earned but for his employer's cessation of business, the District Court disagreed. Relying on the plain meaning of section 28 ("for wages due . . . for labor performed . . . ."), the court concluded that the claimant "has not performed labor, and he is not entitled to wages which are a compensation for labor." ${ }^{45}$ In any event, Congress repealed the 1867 Act in 1878 with little opposition. ${ }^{46}$

\footnotetext{
${ }^{41}$ See In re Harthorn, 11 F. Cas. 705,705 (D. Me. 1870) (No. 6,162) ("Ordered, that fifty dollars of the claim proved by [bankrupt], for services of his minor son ... be allowed and paid as a preferred claim.").

${ }^{42}$ See In re Taylor, 20 F. Cas. 1070, 1070 (D. Mass. 1876) (No. 11,977) (allowing priority for wages for "work of a clerk ... who was only engaged for two weeks, and for [a] single occasion").

${ }^{43}$ See In re Prevear, 19 F. Cas. 405, 406 (N.D.N.Y. 1878) (No. 11,053).

${ }^{44}$ See id. ("The statute manifestly contemplates making provision for laborers and their families whose occupation suggests that they have but limited or moderate means, and whose daily, weekly, or monthly wages are necessary for their support....").

${ }^{45}$ Id. A New York court added concern for the employee's family to the purposes of that state's employee preference law. See People v. E. Remington \& Sons, 45 Hun. 329, 343 (N.Y. Sup. Ct. 1887) (Maule, J., concurring) ("[Statute] was designed to secure the prompt payment of the wages of persons who, as a class, are dependent upon their earnings for the support of themselves and their families . . . ."); see also In re Stryker, 53 N.E. 525, 526 (N.Y. 1899) (explaining that law "was not designed to give a preference to the salaries and compensation due to officers and employees of a corporation occupying superior positions of trust or profit"); In re New York Locomotive Works, 26 N.Y.S. 209, 212 (Gen. Term 1893) (discussing People v. E. Remington \& Sons and concern for families of wage earners).

${ }^{46}$ See Tabb, supra note 10, at 21 ("By all accounts, the sentiment for repeal was overwhelming."); $c f .28$ Cong. Rec. 4612 (1896) (statement of Sen. Burton) ("[T]he crowning evil of the law of 1867 was the enormous fee bill which the register in bankruptcy and the assignee in bankruptcy were enabled to tax up against the estate of a bankrupt ...."); David A. Skeel, The Genius of the 1898 Bankruptcy Act, 15 EMORY BANKR. DEV. J. 321, 330 (1999) (citing desire "to prevent some of the abuses of the 1867 Act" in making 1898 Act); Charles Jordan Tabb, A Century of Regress or Progress? A Political History of Bankruptcy Legislation in 1898 and 1998, 15 EMORY BANKR. DEV. J. 343, 354 (1999) (highlighting "negative experience with the . . 1867 Act" as source of delay in passage of 1898 Act). High fees and expenses contributed to the demise of the 1867 Act. See In re Woodard, 95 F. 955, 956 (E.D.N.C. 1899) ("One of the purposes of the act of 1898 in establishing a uniform system of bankruptcy was to avoid what was the principal cause of the repeal of the bankrupt act of 1867-excessive fees and great expense."); Skeel, supra at 332 (suggesting "costs of administration had left a bad taste in lawmakers' mouths after the $1867 \mathrm{Act}$ ").
} 


\section{B. The 1898 Act}

The Bankruptcy Act of 1898 so far has been the most lasting effort of Congress to legislate in the field of bankruptcy. ${ }^{47}$ The 1898 Act continued to provide priority for wage claims, but the relative priority changed several times. Initially, the priorities of the 1898 Act followed the Act of 1867. Secured claims were unaffected by the Act and secured creditors received their collateral, or its value, before any unsecured creditors. ${ }^{48}$ Section $64 \mathrm{a}$ appeared to provide first priority for taxes, ${ }^{49}$ but section $64 \mathrm{~b}$ went on to provide for all priority claims, including taxes. Wage claims appeared in section $64 \mathrm{~b}$ as a fourth level priority to the extent of three hundred dollars for "wages due to workmen, clerks, or servants" now earned only within three months of the adjudication of bankruptcy. ${ }^{50}$

Judicial analysis of the scope of the priority tended toward the narrow with some exceptions. Learned Hand noted that each member of the trilogy of the 1898 Act (workmen, clerks, and servants) expanded on their predecessors under the 1867 Act. $^{51}$ Yet, earlier he had been unwilling to extend the priority to a manager of a broker's branch office ${ }^{52}$ and fifteen years later he held that "it would be an abuse of

\footnotetext{
${ }^{47}$ See Bankruptcy Act of 1898, ch. 541, 30 Stat. 544 (repealed by Bankruptcy Reform Act of 1978, PUB. L. No. 95-598, 92 Stat. 2549, 2682); $c f$. Hon. Prudence Carter Beatty, Judging at the End of the Millennium, AM. BANKR. INST. J., Nov. 1999, at 28 ("When the U.S. Congress passed the Bankruptcy Act of 1898, it was intended to be a temporary measure. However, there has been a bankruptcy law in continuous effect ever since."); Hon. Leif M. Clark \& Douglas E. Deutsch, New Development: The Delaware Gap: Exposing New Flaws in the Scheme of Bankruptcy Referrals, 5 AM. BANKR. INST. L. REV. 257, 261 (1997) ("[1]n 1898 Congress enacted a bankruptcy act which stood the test of time.").

${ }^{48}$ See Bankruptcy Act of 1898 , supra note $47, \S 67$ (d) ("Liens given or accepted in good faith and not in contemplation of or in fraud upon this Act, and for a present consideration, which have been recorded according to law, if record thereof was necessary in order to impart notice, shall not be affected by this Act.") (emphasis added); In re Proudfoot, 173 F. 733, 734 (C.C.N.D.W. Va. 1909) (clarifying "plain intent of the bankrupt law" that secured creditors take priority over wages due to laborers). But see In re Tebo, $101 \mathrm{~F}$. $419,420-21$ (D.W. Va. 1900) (holding priority wage claims must be paid ahead of liens).

${ }^{49}$ See Bankruptcy Act of 1898 , supra note $47, \S 64$ a ("The court shall order the trustee to pay all taxes legally due and owing by the bankrupt to the United States, State, county, district, or municipality in advance of the payment of dividends to creditors ....").

${ }^{50} I d$. at $\S 64 \mathrm{~b}$. See text of section $64 \mathrm{~b}$, providing for all priority claims, including taxes.

${ }^{51}$ Learned Hand in In re Albert O. Brown \& Co. stated:
}

Act March 2, 1867 [. . .] provided that priority should not be given, except that wages due from him (the bankrupt) to any operative or clerk or house servant' shall be preferred. In the present act [...] the words are workman, clerk, or servant.' 'Workman' is possible a wider phrase than 'operative,' and 'servant' is undoubtedly wider than 'house servant; but the section is obviously copied after the law of 1867.

See In re Albert O. Brown \& Co., 171 F. 281, 281 (S.D.N.Y. 1909) (holding manager was not a "clerk" and therefore not entitled to wage priority).

${ }^{52}$ See id.

It is quite clear that Olmsted is not a 'workman' for the bankrupt. Nor is he a 'servant,' because the term does not include all instances of the formal relation of master and servant [... ] In the more limited sense, it is quite clear that Olmsted is not a 'servant.' 
terms" to allow a "chief designer" of radios to enjoy priority status. ${ }^{53}$ Similarly, other courts jealously guarded the wage priority gate by denying priority status to the president of a bankrupt corporation, ${ }^{54}$ a general manager, ${ }^{55}$ a traveling salesman, ${ }^{56}$ and a commission agent $;{ }^{57}$ although part time clerks who also worked for others enjoyed the priority. ${ }^{58}$ Congress expanded the class of priority wage claimants in 1906 by adding "traveling or city salesmen." ${ }^{59}$ Still, courts continued to

${ }^{53}$ In re Lawsam Electric Co., Inc., 300 F. 736, 736 (S.D.N.Y. 1924).

54 The majority in In re Carolina Cooperage Co. stated:

Slocumb was neither a workman, a clerk, nor a servant, in the sense in which these limiting words are used. If congress had intended this provision to extend to presidents of commercial corporations, it would have said so. Presidents of such corporations do not generally act as workmen, clerks, or servants, but exercise authority over these classes, occasionally arbitrary and oppressive, but always in a way to let them know the president is not one of them.

96 F. 950,952 (E.D.N.C. 1899).

${ }^{55}$ The majority in In re Grubbs-Wiley Grocery Co. stated:

Ordinarily a workman is understood to be 'one who labors . . . one who is employed in labor.' Doubtless the statute has reference to a workman employed on some character of work,-laboring for some person who sustains to him the relation of an employer or master, for whom he works. So, also, the term 'servant' ordinarily means a person employed by another to render personal services to the employer . . . . This claimant was himself a stockholder . . . and was one of the board of directors, and was its general manager . . . . He was not a servant, as he had no master over him [. . .] It is true, he was, in a certain sense, working for the corporation, the legal entity; but . . . he was the representative of the corporate body.

96 F. 183, 184 (W.D. Mo. 1899). After explaining why the claimant should not enjoy priority status, the District Court went on to affirm the decision of the referee to allow priority status for the reasonable value of the claimant's services. See id. at 185 .

${ }^{56}$ See In re Scanlan, 97 F. 26, 27 (D. Ky. 1899) (using various dictionary definitions to determine meaning of three statutory words). But see In re Flick, 105 F. 503, 505 (S.D. Ohio 1900) ("But I am inclined to the opinion, and will so hold, that a salesman, properly speaking, will come within the term 'clerk,' and is entitled to priority.").

${ }^{57}$ See In re Mayer, 101 F. 227, 227 (E.D. Wis. 1900) ("[T]he commission service was merely an incidental agency in procuring customers, with no obligation to serve, and the claim is not one entitled to priority ... ."); see also In re Crawford Wollen Co., 218 F. 951, 954 (N.D. W. Va. 1915) ("[A]gents selling on salary or on commission were held to be outside the privileges of section $64 \mathrm{~b}, \mathrm{cl} .4$, of the Bankruptcy Act."); In re Caldwell, 164 F. 515, 516 (E.D. Ark. 1908) (observing Congress specifically amended act to avoid strict judicial construction holding salesmen not protected class).

${ }^{58}$ See In re Baublatt, 156 F. 422, 423 (E.D. Pa. 1907) ("Exclusive employment by the bankrupt has never been considered necessary to constitute the claimant a clerk . . . ."); see also In re H. O. Roberts Co., $193 \mathrm{~F}$. 294, 295 (D. Minn. 1912) ("If the labor performed by him is so performed under his employment as clerk, and is not performed as a part of his duties as an officer, then he is entitled to priority for his wages as a clerk."). But see In re L. W. Birmingham \& Son Co., 1 F.2d 511,511 (E.D. Tenn. 1924) (finding manager who performed functions of clerk in connection with duties as treasurer could not claim priority).

${ }_{59}$ Act of June 15, 1906, ch. 3333, 34 Stat. 267 (amending statute to include traveling or city salesmen). See Crawford Wollen Co., 218 F. at 954 (noting 1906 Amendment of Bankruptcy Act section 64b, cl. 4, expressly included traveling salesmen and agents selling on salary or commission); Caldwell, $164 \mathrm{~F}$. at 516 ("When Congress found that some of the courts, giving that provision of the act a strict construction, had 
treat the scope of the wage priority narrowly by excluding payments due for managing an "outsourced" but in-house department of a manufacturing company, ${ }^{60}$ a plant superintendent who performed extensive manual labor, ${ }^{61}$ a general manager and shop superintendent, ${ }^{62}$ or a teacher. ${ }^{63}$ Even a surety who had advanced funds to the bankrupt for payment of wages could not be subrogated to the wage-earners' priority, ${ }_{65}^{64}$ although a specific wage assignment did carry the wage-earner's priority. $^{65}$

held that a traveling salesman was not within the classes mentioned, it amended the act so as to avoid that construction by adding the words 'traveling or city salesmen."') (citations omitted).

${ }^{60}$ See In re Thomas Deutschle \& Co., 182 F. 430, 434 (M.D. Pa. 1910) ("[T]he remuneration to which he was entitled was not wages but an agreed price for articles produced, which the law does not undertake to preferentially provide for."); see also In re Bonk, 270 F. 657, 659 (E.D. Mich. 1920) (denying priority claim where claimant managed store based on contract with bankrupt and exercised discretion in performance of duties); In re Quackenbush, 259 F. 599, 601 (D.N.J. 1919) (finding person under contractual agreement with bankrupt to run stamp business is not salesman or servant within meaning of Bankruptcy Act).

${ }^{61}$ See In re Continental Paint Co., 220 F. 189, 190 (N.D.N.Y. 1915); see also Wright v. Chase Nat'l Bank of City of New York, 92 F.2d 271, 272 (4th Cir. 1937) ("Services rendered or labor performed as incidental to the duties of a manager in charge do not make one either a laborer or a traveling representative."); In re Crown Point Brush Co., 200 F. 882, 886 (N.D.N.Y. 1912) (finding assistant general manager's duties involving some physical activity and labor "did not necessarily constitute him a workman or servant").

${ }^{62}$ See Blessing v. Blanchard (In re Pacific Motor Car Co.), 223 F. 35, 37 (9th Cir. 1915) ("We think the word 'servant' should be held to mean a restricted class of subordinate helpers who work for wages ...."); see also In re Pac. Oil \& Meal Co., 24 F. Supp. 767, 770 (S.D. Cal. 1938) ("Congress certainly never intended that wage claims of officers of a corporation-even minor officers-who are in any way responsible for management or who assist in policy forming should be given priority over the claims of general creditors."); In re Broudarge Bros. Novelty Yarn, Inc., 22 F. Supp. 891, 891 (E.D.N.Y. 1938) ("[I]t has been held that a general manager of a store even though he at times sold goods and at times rendered clerical services, was not entitled to priority.").

${ }^{63}$ See In re Estey, 6 F. Supp. 570, 570-71 (S.D.N.Y. 1934) (holding that a teacher is not a "workman," "clerk," "salesman," or "servant"); see also In re Lawsam Elec. Co., 300 F. 736, 736 (S.D.N.Y. 1924) ("The statute was intended to favor those who could not be expected to know anything of the credit of their employer, but must accept a job as it comes, to whom the personal factor in employment is not a practicable consideration."); In re Gay \& Sturgis, 233 F. 604, 605 (D. Mass. 1916) ("I doubt whether the earnings of a professional man, employed primarily because of his learning and his ability to advise helpfully, are properly described as 'wages' ....").

${ }^{64}$ See United Sur. Co. v. Iowa Mfg. Co., 179 F. 55, 58 (8th Cir. 1910) (characterizing transaction as simple loan rather than purchase of claims from workers which would secure some equitable right against principal debtor deserving priority). Compare In re Allen Carpet Shops, Inc., 27 B.R. 354, 358 (Bankr. E.D.N.Y. 1983) (holding bank cashing wage checks constituted overdraft or loan, not intentional assignment of wage claims so not entitled to priority) with Wilson v. Brooks Supermarket, Inc. (In re Missionary Baptist Found. of Amer.), 667 F.2d 1244, 1247 (5th Cir. 1982) ("Under the former Bankruptcy Act of 1898, the judicial policy to allow priority to assigned wage claims was designed for the protection of the worker, who is thereby enabled to liquidate his claim against the bankrupt more advantageously.").

${ }^{65}$ See Shropshire, Woodliff \& Co, v. Bush, 204 U.S. 186 (1907) (holding assigned wages had priority in bankruptcy); see also Wilson v. Brooks Supermarket (In re Missionary Baptist Found. of America, Inc.), 667 F.2d 1244, 1247 (5th Cir. 1982) (affirming principle set forth in Shropshire and indicating unless there is clear legislative intent in Bankruptcy Code not to allow transferees to stand in shoes of transferors, transferees' position does not change by transfer); Local 140 Security Fund v. Hack, 242 F.2d 375, 377 n.5, 378 n.6 ( $2 \mathrm{~d}$ Cir. 1957) (holding "where collective bargaining agreement provided only for payments by employer to welfare fund, with no assignment or deduction of workmen's wages, welfare fund was not entitled to wage claim priority against bankrupt employer"). 
Under the 1898 Act courts again articulated a paternalistic rationale for the wage priority. "All creditors are supposed to stand upon an equal footing before the law . . ..." Nonetheless, courts frequently observed that "[t]he bankruptcy act, while primarily intended to secure an equal distribution of the assets of the bankrupt among his creditors, evinces a strong intent on the part of Congress to protect those who are dependent on their daily earnings for their support . ..."67 Advancing this paternalistic argument the Ninth Circuit recognized the precarious nature of working class life when it remarked that "[p]riority of payment was intended for the benefit only of those who are dependent upon their wages, and who, having lost their employment by the bankruptcy, would be in need of such protection." ${ }^{68}$ Even the Supreme Court acknowledged this rationale in 1912 in Guaranty Title when it held that the wage claims under the 1898 Act had priority over the contractual obligations due to the United States. ${ }^{69}$ However, anticipating concerns for nonadjusting creditors, which would be more specifically articulated forty years later, ${ }^{70}$ the District Court articulated a different ground for the priority when it noted that typical wage-earners cannot be "expected to know the credit standing of their employer but must accept employment as it comes." 71

Thus, three factors animated the courts' application of section $64 \mathrm{~b}$ (and, after 1938, section 64a): a strong emphasis on creditor equality coupled with the assertion that typical employees could not effectively protect their interests, and

${ }^{66}$ In re Flick, 105 F. 503, 507 (S.D. Ohio 1900).

${ }^{67}$ In re Caldwell, 164 F. 515, 516 (E.D. Ark. 1908).

${ }^{68}$ Blessing v. Blanchard (In re Pacific Motor Car Co.), 223 F. 35, 37 (9th Cir. 1915).

${ }^{69}$ See Guarantee Title \& Trust Co. v. Title Guar. \& Sur. Co., 32 S. Ct. 457, 460 (1912)

The policy which dictated it was beneficent and well might induce a postponement of the claims, even of the sovereign, in favor of those who necessarily depended upon their daily labor. And to give such claims priority could in no case seriously affect the sovereign. To deny them priority would in all cases seriously affect the claimants.

\footnotetext{
${ }^{70}$ Professors Lucian Arye Bebchuk and Jesse M. Fried seems to have introduced the term "nonadjusting creditor" in their seminal work The Uneasy Case for the Priority of Secured Claims in Bankruptcy. As they later explained,
}

[a] 'nonadjusting' creditor is a creditor that, for one reason or another, cannot or does not adjust the terms of its loan to reflect the effect on its loan of all the arrangements the borrower enters into with other creditors, including the creation of security interests which, under full priority, completely subordinate the nonadjusting creditors' claim in bankruptcy.

Lucian Ayre Bebchuk \& Jesse M. Fried, The Uneasy Case for the Priority of Secured Claims in Bankruptcy: Further Thoughts and a Reply to Critics, 82 CORNELL L. REV. 1279, 1295-96 (1997). See Hanoch Dagan, Restitution in Bankruptcy: Why All Involuntary Creditors Should Be Preferred, 78 AM. BANKR. L.J. 247, 277 (2004) (noting Bebchuk and Fried's observation "non-adjusting" creditors cannot or do not adjust terms of loan to reflect effect of all arrangements borrower enters into with other creditors on loan); Alan Schwartz, Bankruptcy Contracting Reviewed, 109 YALE L.J. 343, 362 (1999) ("A non-adjusting creditor . . . charge[s] the lower pro rata interest rate either because it is unsophisticated or because the cost of altering its contracts deal by deal would be too high in relation to the gains.").

${ }^{71}$ In re Inland Waterways, Inc., 71 F. Supp. 134, 136 (D. Minn. 1947). 
thirdly, recognition that Congress had acted to protect several sets of employees who were especially dependent upon wages for survival and whose necessity made them particularly subject to the vagaries of the labor market. ${ }^{72}$ Section $64 \mathrm{~b}$ (and later section 64a) was narrowly construed from all three directions. Only those closely hewing to the courts' cabined understanding of the enumerated categories would enjoy a priority. ${ }^{73}$

As part of the continuing political legacy of the Depression, in 1938 Congress again amended the 1898 Act with the Chandler Act. ${ }^{74}$ A restated section 64 a now contained all priorities and arrayed creditors among five classes:

1. Administrative expenses;

2. Wage claims;

3. Expenses of creditors who successfully blocked an arrangement, plan, or discharge;

4. Taxes due to the United States or any state; and

5. Any other debts granted priority by a law of the United States and rent claims entitled to priority under state law. ${ }^{75}$

${ }^{2}$ See In re Flick, 105 F. 503, 507 (S.D. Ohio 1900) (recognizing importance of creditor equality); Caldwell, $164 \mathrm{~F}$. at 516 (noting Congress' intention to protect workers who are dependent on their daily earnings for their support); In re Lawsam Electric Co., Inc., 300 F. 736 (S.D.N.Y. 1924) (refusing claim for wages because claimant was not in disadvantaged position of workman or servant). As Learned Hand put it, "[t]he statute was intended to favor those who could not be expected to know anything of the credit of their employer, but must accept a job as it comes, to whom the personal factor in employment is not a practicable consideration." Id. Class bias was also at work. According to Hand, a radio engineer "is not in the same economic class as the workers [and] . . . would have been the first to resent the notion that he was a workman or a servant." Id. Of course, the engineer had sought priority for his unpaid wages, which seems to belie Hand's characterization of the claimant's putative class consciousness.

${ }_{73}$ The continuing confusion over the level of tax claim priority led Congress to enact substantial amendments in 1926 that clarified the priority of tax claims. However, the 1926 amendments went on to subordinate wage claims to a new priority for the expenses of creditors who opposed confirmation of a composition. But the amendments also increased the wage priority to six hundred dollars. See Act of May 27, 1926, 44 Stat. 662; see also Tabb, supra note 10, at 27 (noting attempts made to "ameliorate the perceived extreme pro-debtor orientation of the 1989 Act"). See generally Ralph H. Colin, An Analysis of the 1926 Amendments to the Bankruptcy Act, 26 CoLUM. L. REV. 789, 789 (1926) (stating, in regard to 1926 amendments, that "new amendments should go a long way toward effectuating a conformity in the theory and practice of our bankruptcy law" concerning discharge in bankruptcy).

${ }^{74}$ See Chandler Act, Act of June 22, 1938, ch. 575, 52 Stat. 840 (1938) (repealed by Bankruptcy Reform Act of 1978, Pub. L. No. 95-598, 92 Stat. 2549, 2682); Tabb, supra note 10, at 28 ("After the Depression came crashing down in 1929, Congress passed several pro-debtor amendments that facilitated rehabilitation through bankruptcy. Severe restraints were laid upon the ability of creditors to collect, even upon their collateral."); Tabb, supra note 10, at 29 ("The fury of bankruptcy legislation came to a head in 1938 with the passage of the comprehensive Chandler Act .... The Chandler Act substantially revised virtually all of the provisions of the 1898 Act."); Anupama Yerramalli, Note, Deciphering the Statutory Language of II U.S.C. Section 1102(b)(3): Information Disclosure Requirements Imposed Upon Creditors' Committees, 15 AM. BANKR. INST. L. REV. 361, 376 n.95 (2007) ("The Bankruptcy Act of 1898 remained in effect until it was replaced by the Bankruptcy Reform Act of 1978 . However, the 1898 Act was largely amended in 1938 by the Chandler Act.").

${ }^{75}$ See Chandler Act, supra note 73. 
Unsurprisingly, given the political dynamics of the 1930s, holders of wage claims were the clear beneficiaries of the 1938 amendments. Congress repositioned the wage priority upward and slightly broadened the class of its beneficiaries, clarifying that part-time and non-exclusive traveling salesmen also enjoyed priority. ${ }^{76}$ Yet the apparent improvement of priority for wage claims was tempered because three priorities of the preceding version of the statute were folded into an enhanced category of administrative claims. ${ }^{77}$ With their move to a second priority position, unpaid wage earners enjoyed their highest priority ever. And for the first time Congress subordinated all federal claims, including tax claims, to those of wage earners.

The 1898 Act continued to undergo modifications until its repeal in $1978 .^{78}$ None of these later amendments changed the high priority status of wage claims afforded with the 1938 Chandler Act. ${ }^{79}$ Yet at all times under the 1898 Act, and notwithstanding the continued permutation and expansion of its priority provisions, the Court continued to assert that "the broad purpose of the Bankruptcy Act is to bring about an equitable distribution of the bankrupt's estate among creditors."

${ }^{76}$ See 3A COLliERS ON BANKRUPTCY II 64.201 [2.2] (1967); Chasing the Lien Through 67b of the Bankruptcy Act, 3 STAN. L. REV. 711, 718 n.30 (1951) ("Prior to the 1938 amendments, priority was given in bankruptcy to debts entitled to priority under state law."); John C. McCoid, II, Statutory Liens in Bankruptcy, 68 AM. BANKR. L.J. 269, 275-76 (1994) ("The 1938 legislation put caps on wage and rent liens on personal property not accompanied by possession.").

${ }^{7}$ See Colliers, supra note 76; see also Judge John H. Squires \& Susan M. Pistorius, The Evolution of Bankruptcy Law in the Northern District of Illinois, 10 DEPAUL BUS. L.J. 27, 52 (1997) ("One of the most important revisions was the addition of Chapter XIII for the purpose of providing a method by which a wage-earner debtor could pay his creditors in full in installments or effect a composition by payment of a percentage of his debts over a period of time."); Jack F. Williams, National Bankruptcy Review Commission Tax Recommendations: Individual Debtors, Priorities, and Discharge, 14 BANKR. DEV. J. 1, 43 (1997) (noting "there is a long-standing policy beginning with the 1938 Chandler Act amendments that has subordinated tax liens to administrative expenses").

${ }^{78}$ See Alan J. Feld, Note, The Limits of Bankruptcy Code Preemption: Debt Discharge and Voidable Preference Reconsidered in Light of Sherwood Partners, 28 CARDOZO L. REV. 1447, 1455 n.42 (2006) ("Though there were a number of amendments to the $1898 \mathrm{Act}$, major reforms in some areas were enacted through the Bankruptcy Reform Act of 1978 ...."); Phillip J. Giese, Note, Till v. SCS Credit Corp.: Can You "Till" Me How to Cram This Down? The Supreme Court Addresses the Proper Approach to Calculating Cram Down Interest Rates, 33 PEPP. L. REV. 133, 137 (2005) ("Although the 1898 Act enjoyed a long tenure, it was amended several times-most notably by the Chandler Act of 1938."); Eric A. Posner, The Political Economy of the Bankruptcy Reform Act of 1978, $96 \mathrm{MICH}$. L. REV. 47, 61 (1997) ("Moreover, Congress had amended the 1898 Act many times, and courts had interpreted the 1898 Act and its amendments in an aggressive way, resulting in a law of bankruptcy that often bore little relation to the statutory text."); Tabb, supra note 10, at 30 ("Over the next forty years, Congress amended the bankruptcy laws dozens of times ....").

${ }^{79}$ See Act of July 30,1956 , ch. 784, Pub. L. No. 840 (1956) (widening definition of traveling salesmen in 1956); Act of July 5, 1966, Pub. L. No. 89-496, 80 Stat. 270 (1966) (repealed 1978) (modifying extent of priority of tax claims in 1966); see also McCoid, supra note 76, at 280 ("Though not similarly protected in the fourth draft, wage claims given priority attained that advantage in the fifth and the final drafts.").

${ }^{80}$ Kothe v. R.C. Taylor Trust, 280 U.S. 224, 227 (1930). See Kuehner v. Irving Trust Co., 299 U.S. 445 , 451 (1937) ("[T]he object of bankruptcy laws is the equitable distribution of the debtor's assets amongst his creditors . . . .); Tabb, supra note 10, at 25 ("Much of the 1898 Act was directed not at debtor relief, but rather at facilitating the equitable and efficient administration and distribution of the debtor's property to creditors."). 
Employee benefits other than wages achieved substantial prominence after World War II. ${ }^{81}$ Thus it is not surprising that the question of whether the wage priority extended to such benefits eventually came to the fore. The Supreme Court decided two benefits priority cases under the 1898 Act. In United States v. Embassy Rest., Inc. ${ }^{82}$ a six-member majority held that mandatory employer contributions to a union welfare fund required under a collective bargaining agreement did not qualify as "wages . . . due to workmen. ${ }^{183}$ The majority concluded that the contributions were neither wages nor were they due the employees. The contributions, even though mandatory, were just that-contributions. ${ }^{84}$ Further, they were not due to "workmen" because the contributions were to be paid to the trustees of the welfare funds maintained by unions. ${ }^{85}$ Nor, the Court noted, were the contributions held in separate accounts for the benefit of specific members. ${ }^{86}$

The majority also cited principal and pragmatic reasons for its decision. Citing one of its earlier bankruptcy cases for the proposition that "[t]he broad purpose of the Bankruptcy Act is to bring about an equitable distribution of the bankrupt's estate" ${ }^{187}$ and a labor case for the axiom that exemptions are to be strictly construed ${ }^{88}$ the Court noted that the wage priority pre-dated the existence of non-

81 See Bruce G. Carruthers \& Terence C. Halliday, Rescuing Business: The Making of CORPORATE BANKRUPTCY LAW IN ENGLAND AND THE UNITED STATES 328 (Clarendon Press 1998) ("In the post-World War II period, employee compensation increasingly consisted of both wages and benefits."); see also Michael S. Gordon, Overview: Why Was ERISA Enacted?, in PENSION AND EMPLOYEE BENEFIT LAW 73, 75 (John H. Langbein \& Bruce A. Wolk eds., 2000); C. Scott Pryor, Rock, Scissors, Paper: ERISA, The Bankruptcy Code and State Exemption Laws for Individual Retirement Accounts, 77 AM. BANKR. L.J. $65,69-70$ (2003) ("Congress wished to encourage growth of pension plans and to protect participants in an beneficiaries of such plans when it enacted ERISA.").

82359 U.S. 29 (1959).

${ }^{83} \mathrm{Id}$. at 35.

${ }^{84}$ See id. at 32-33 ("[I]t does not appear that the parties to the collective agreement considered these welfare payments as wages. The contract here refers to them as 'contributions."'); see also Local $140 \mathrm{Sec}$. Fund v. Hack, 242 F.2d 375, 378 (2d Cir. 1957) (explaining payments by employer to security fund created only debtor creditor obligation between employer and third parties for something other than wages); In re Int'l Automated Machs., 13 B.R. 119, 120-21 (Bankr. N.D. Ohio 1981) (allowing employer contributions only general priority status).

${ }^{85}$ See Embassy Rest., 359 U.S. at 33 ("Embassy's obligation is to contribute sums to the trustee, not to its workmen; it is enforceable only by the trustees who enjoy not only the sole title, but the exclusive management of the funds."); see also In re Brassel, 135 F. Supp. 827, 830 (N.D.N.Y. 1955) (holding employee never had property interest in employer's contribution to fund since trustee's discretion in administration of fund was "final and conclusive"); Local 140 Sec. Fund, 242 F.2d at 378-79 (Hincks, J., concurring) (concluding denial of priority claim is proper because "it is self-evident that the appellant-Fund is not a workman").

${ }^{86}$ See Embassy Rest., 359 U.S. at 32 ("[These contributions] are flat sums of $\$ 8$ per month for each workman. The amount is without relation to his hours, wages or productivity."); see also In re A \& S Elec. Corp., 379 F.2d 211, 212 (2d Cir. 1967) (holding contributions did not have customary attributes of wages because they were flat sums); Sulmeyer v. S. Cal. Pipe Trades Trust Fund, 301 F.2d 768, 771 (9th Cir. 1962) (finding contributions to holiday fund were "wages" because were based on percentage of employee's wages and tax, social security and unemployment compensation were withheld).

${ }^{87}$ See Embassy Rest., 359 U.S. at 31 (quoting Kothe v. R.C. Taylor Trust, 280 U.S. 224, 227 (1930)).

${ }^{88}$ See id. ("[1]f one claimant is to be preferred over others, the purpose should be clear from the statute." (quoting Nathanson v. NLRB, 344 U.S. 25, 29 (1952))); see also In re Boston Reg. Med. Ctr., Inc., 265 B.R. 838,851 (B.A.P. 1st Cir. 2001) (noting "equality of distribution" principle calls for strict construction of 
wage employee benefits and that the "few and guarded amendments" subsequent to 1898 evidenced Congress' limited solicitude for employees. ${ }^{89}$ Re-emphasizing the employee-trustee distinction, the majority also expressed a new concern: that permitting benefits contributions to share priority with employee wages would end up "reducing his own recovery," ${ }^{90}$ an anti-dilution argument. Finally, the Court returned to the paternalistic principle of its 1912 Guarantee Title ${ }^{91}$ decision by restating what it believed to be the fundamental policy of the wage priority: "the purpose of Congress has constantly been to enable employees displaced by bankruptcy to secure, with some promptness, the money directly due them in back wages, and thus to alleviate in some degree the hardship that unemployment usually brings to workers and their families." ${ }^{92}$ Regardless of the pedantic logic of the Court's reasoning, the unique dependence on wages for the masses in the labor market and a heightened concern for the effects of unemployment on closely related third parties clearly animated the majority's analysis.

Nine years later another six-member majority held that unpaid mandatory contributions to an annuity plan that were credited to the accounts of specific employees were not priority claims. In Joint Indus. Bd. v. United States ${ }^{93}$ the Court extended the holding of Embassy Rest. to an obligation to an annuity payable upon the employee's death, retirement, or disability. ${ }^{94}$ Although crediting the contributions to an employee's individual account looked more "wage-like" than the non-allocated welfare benefits addressed in Embassy Rest., the majority cited three principal reasons for not relaxing its prior narrow construction. The Court first reiterated the fundamental purpose for the wage priority it had identified in Guarantee Title and Embassy Rest.: promptly to secure back pay to alleviate "the hardship that unemployment usually brings to workers and their families." ${ }^{95}$ The majority reasoned that the annuity benefits were thus not wage-like because "nothing was payable to employees except upon the occurrence of certain events." Retirement benefits, even though negotiated as part of the employee's compensation

federal bankruptcy priority statute); In re Little, 216 B.R. 769, 770 (Bankr. E.D.N.C. 1997) (explaining sections of Bankruptcy Code giving one creditor priority over another must be strictly construed).

${ }^{89}$ Embassy Rest., 359 U.S. at 32

This class of claim has been given a preferred position in the Bankruptcy Act for over 100 years, long before welfare funds played any part in labor negotiations. True, the Congress has amended the Act, but such amendments have been few and guarded ones, such as raising the ceiling on the amount permitted, shifting the relative priorities and enlarging the class to salesmen, clerks, etc.

\footnotetext{
${ }^{90}$ Id. at 34 .

${ }^{91}$ See supra text accompanying note 68 .

${ }^{92}$ Nathanson v. NLRB, 344 U.S. 25,29 (1952).

93391 U.S. 224 (1968).

${ }^{94}$ Id. at 225-26 ("Contributions received by the trustees are credited to the account of the individual employees but are 'payable to him . . .' upon death, retirement from the industry at age 60 , permanent disability, entry into the Armed Forces, or ceasing to be a participant under the plan.").

${ }_{95}$ Id. at 226-227 (quoting Embassy Rest., 359 U.S. at 32 (1959)).

${ }^{96} I d$.
} 
package, were not wages because they were not currently available to the employee. ${ }^{97}$ The majority next returned to its pragmatic anti-dilution rationale:

If delinquent contributions to welfare and annuity funds providing deferred benefits to employees were to have equal priority with wages payable directly to employees, the maximum payable immediately and directly to employees would be reduced whenever the individual wage claims approached $\$ 600$ or whenever the assets of the estate would not permit all wage claims to be paid in full. ${ }^{98}$

In dicta, the majority extended this reasoning to the protection of junior priority creditors, particularly citing concern for fourth priority claims such as workers compensation. ${ }^{99}$ Finally, the Court noted that Congress had reenacted section 64a of the 1898 Act after Embassy Rest. without change, from which it inferred Congressional acquiescence in its earlier decision. ${ }^{100}$ The Court's paternalistic concern arising out of the dependence of most employees on quick payment of wages to allow them to buy their daily bread constrained its interpretation of "wages." Its pragmatic concern about the effects of broadening the wage priority on both wage earners and those lower on the priority list solidified the Court's conclusion that any change in the scope of the wage priority should come from Congress.

\section{The 1978 Code}

Work on completely reworking the Bankruptcy Act of 1898 began with a Joint Resolution in $1968,{ }^{101}$ culminating with the creation the Commission of the

\footnotetext{
${ }^{97}$ See Joint Indus. Bd. of Elec. Indus. v. U.S., 391 U.S. 224, 227-28 (1968) ("[T]he employee could not assign, pledge, or borrow against the contributions, or otherwise use them as his own. Quite obviously the annuity fund was not intended to relieve the distress of temporary unemployment, whether arising from the bankruptcy of the employer or for some other reason.").

${ }_{98}^{98}$ Id. at 228-29.

${ }^{99}$ See id. ("[I]ncreasing the amounts payable to second priority creditors would reduce the assets available for distribution to lower priority claimants and general creditors, including wage claimants not entitled to priority."). The Court specifically addressed the negative impact of expanding the wage priority on various taxes in a footnote.
}

It is instructive that workmen's compensation claims were not provable in bankruptcy until 1934, when they were given a seventh priority. In 1938 the priority for compensation claims was abolished. Moreover, taxes and Social Security contributions which are withheld from wages are entitled to a fourth priority as taxes rather than a second priority as wages.

Id. at 229 n. 7 .

${ }^{100} I d$. at 228 . ("Although the section was completely re-enacted in $1967, \S 64$ a (2), was left unchanged despite the fact that in every Congress since Embassy Restaurant bills have been introduced to overrule or modify the result reached in that case.").

${ }^{101}$ See S.J. Res. 100, 90th Cong., § 2(a) (1968). 
Bankruptcy Laws of the United States in $1970 .{ }^{102}$ Congress eventually enacted the Bankruptcy Reform Act of $1978,{ }^{103}$ which created section 507(a)(3), the Bankruptcy Code's version of the wage priority. Congressional action between 1978 and 2005 had little substantive effect on the wage priority. The Bankruptcy Reform Act of 1994 slightly broadened the scope of the priority to cover commissions generated by certain independent contractors. ${ }^{104}$ The 1994 Act also increased the maximum amount eligible for the wage priority. ${ }^{105}$ In 2005 , however, Congress enacted the Bankruptcy Abuse Prevention and Consumer Protection Act of 2005, which moved what had been the seventh priority for alimony, maintenance, and support to a new first priority for domestic support obligations. ${ }^{106}$ This change had the effect of moving the wage priority down one place, but given the infrequency of significant wage claims in individual bankruptcies, it should not have substantial distributional effects.

\section{HOWARD DELIVERY SERVICE V. ZURICH AMERICAN INSURANCE}

Howard Delivery Service (hereinafter "Howard") was an erstwhile West Virginia-based interstate freight carrier that operated in a dozen states and employed nearly 500 people. ${ }^{107}$ Howard had contracted with Zurich to provide it with workers' compensation insurance in ten of those states. ${ }^{108}$ By the time Howard filed chapter 11 in January of 2002, it owed Zurich upwards of $\$ 400,000$ in unpaid workers' compensation insurance premiums. ${ }^{109}$ Zurich ultimately filed a proof of claim for $\$ 410,215$ that asserted priority under section $507(\mathrm{a})(4)$, for "contributions to an employee benefit plan. ${ }^{110}$ Howard objected to Zurich's claim of priority status and the Bankruptcy Court upheld the objection. ${ }^{11}$ The District Court affirmed. ${ }^{112}$ Zurich then appealed to the Fourth Circuit, which reversed, 2 to $1 .{ }^{113}$ Each of the

${ }^{102}$ See Law of July 24, 1970, Pub. L. No. 91-354, 84 Stat. 468 (1970)

${ }^{103}$ See Pub. L. No. 95-598, 92 Stat. 2549 (1978).

${ }^{104}$ See Pub. L. No. 103-394, § 207 (1994); In re Classic Auto Painting \& Bodyworks, Inc., No. 93-40730, 1997 WL 33477610, at*1, n.1 (Bankr. S.D. Ga. June 5, 1997) ("The Bankruptcy Reform Act of 1994 amended Section 507(a)(3) to increase the allowed amount to $\$ 4,000$ and permit claims by independent sales representatives . . . ."); David G. Hicks, The October Surprise: The Bankruptcy Reform Act of 1994-An Analysis of Title II-The Commercial Issues, 29 CREIGHTON L. REV. 499, 509 (1996) ("[S]ection 207 does nothing more nor less than increase the earned wages priority of Code section 507 (a)(3) from $\$ 2,000.00$ to $\$ 4,000.00$ and clarifies that this protection extends to certain independent sales representatives.").

${ }_{105}$ See Pub. L. No. 103-394, § 108(c) (1994).

${ }_{106}$ See Pub. L. No. 109-8, \& 802(d)(7); see also GovTrack.us, S. 256 (109th): Bankruptcy Abuse Prevention and Consumer Protection Act of 2005, http://www.govtrack.us/congress/bill.xpd?bill=s109-256 (last visited February 15, 2008).

${ }_{107}^{10}$ See Howard Delivery Serv., Inc. v. Zurich Am. Ins. Co., 126 S. Ct. 2105,2109 (2006).

${ }_{108}^{108} I$.

${ }^{109}$ Id.

${ }^{110} I d$. at 2110

${ }^{111} I d$. at $2109-10$

112 Id. at 2010.

${ }^{113}$ Howard Delivery Serv., Inc. v. Zurich American Ins. Co. (In re Howard Delivery Serv., Inc.), 403 F.3d 228, 230 (4th Cir. 2005). 
judges wrote separately and the two who voted to reverse did not agree on a rationale. ${ }^{114}$ Only Judge Niemeyer in dissent anticipated the Court's construction against expanding priorities in his substantial use of Joint Indus. Bd. and Embassy Rest. ${ }^{115}$

The Fourth Circuit was not the first to consider the claim of priority for unpaid workers' compensation premiums. Over a decade earlier the Ninth Circuit held that workers' compensation insurance was an "employee benefit" plan. ${ }^{116}$ The court concluded that neither the statutory mandate of workers' compensation nor the fact that workers' compensation was not a "wage substitute" could deny unpaid insurance premiums their bankruptcy priority. ${ }^{117}$ The two decisions intervening before the Fourth Circuit's opinion in Howard Delivery went the other way. The Eighth $^{118}$ and Tenth ${ }^{119}$ Circuits agreed that the legislative history of section 507(a)(4) excluded workers' compensation from its scope. The latter circuits held that only bargained-for benefits enjoyed priority.

For the third time when considering the priority of employee benefits the Supreme Court split 6 to 3. Justice Ginsburg wrote the majority opinion in which Chief Justice Rehnquist and Justices Stevens, Scalia, Thomas, and Breyer joined. ${ }^{120}$ Justices Souter and Alito joined Justice Kennedy's opinion in dissent. ${ }^{121}$ The majority in Howard Delivery limited its analysis of the history of what had become codified at section $507(a)(5)^{122}$ to the comments of the House ${ }^{123}$ and Senate

${ }^{114} I d$. at 229. Judge King asserted that " $[\mathrm{t}]$ he language of the Statute is plain and unambiguous," and, by consulting several dictionaries, concluded that Zurich's claim should enjoy priority status. Id. at 235, 237. Judge Shedd disagreed with Judge King's first conclusion, holding that "the phrase as a whole [is] ambiguous." Id. at 239. After consulting the legislative history and ERISA, held that Congress intended that "the workers' compensation insurance plan at issue in this case qualif[y] as an 'employee benefit plan.'" Id. at 239, 241. Judge Niemeyer in dissent agreed that the meaning of statutory phrase was plain but, after consulting Supreme Court precedent, concluded that the statute does "not give priority to claims for unpaid workers' compensation insurance premiums." Id. at 245 .

${ }^{115} \mathrm{Id}$. at $244-45$ ("To read $\S 507(\mathrm{a})(4)$ as expansively as do the opinions of Judge King and Judge Shedd not only disregards the explicit language of the statute, but such a reading also violates the underlying ground rules for construing priorities under the Bankruptcy Code.").

${ }^{116}$ Employers Ins. of Wausau v. Plaid Pantries, Inc. (In re Plaid Pantries, Inc.), 10 F.3d 605, 607 (9th Cir. 1993).

117 Id. at 607.

${ }^{118}$ See Employers Ins. of Wausau, Inc. v. Ramette (In re HLM Corp.), 62 F.3d 224, 226 (8th Cir. 1995); see also 11 U.S.C. \$ 507(a)(4) (2006); In re Shearon, 10 B.R. 626, 627 (D. Neb. 1981) ("The fourth priority covers all 'forms of employee compensation ... not in the form of wages."').

${ }^{119}$ See State Ins. Fund v. S. Star Foods, Inc. (In re S. Star Foods, Inc.), 144 F.3d 712, 716 (10th Cir. 1998); see also 11 U.S.C. § 507(a)(4) (2006).

${ }^{120}$ Howard Delivery Serv., Inc. v. Zurich Am. Ins. Co., 126 S. Ct. 2105, 2108 (2006).

${ }^{121}$ Id. at 2117.

122 See generally 11 U.S.C. $\$ 507(a)(5)$ (2006) (placing "unsecured claims for contributions to an employee benefit plan" fifth in priority); As the Court noted:

At the time respondent Zurich American Insurance Company (Zurich) claimed priority treatment for unpaid workers' compensation premiums, the relevant subsections were numbered (a)(3) (wages) and (a)(4) (employee benefit plans). The Bankruptcy Abuse Prevention and Consumer Protection Act of 2005 . . altered the priority list so that (a)(3) became (a)(4), and (a)(4) became (a)(5). 
Reports ${ }^{124}$ about its two earlier cases, Joint Indus. Bd. and Embassy Rest. It was thus "beyond genuine debate," according to Justice Ginsberg, that "the main office of $\S 507(a)(5)$ is to capture portions of employee compensation for services rendered not covered by $\$$ 507(a)(4)." And this "main office" did not extend to unpaid workers' compensation insurance premiums. In other words, only "fringe benefits [that] generally complement, or 'substitute' for, hourly pay"125 enjoy priority status. And workers' compensation premiums did not fall into the wage substitute or even wage compliment categories.

The majority buttressed its narrow reading of section 507(a)(5) from three directions: first, the broader ERISA definition of employee benefits was inapplicable to construction of the Bankruptcy Code, second, workers' compensation is not a uniquely employee benefit, and the long-standing twin policies of equality of distribution and third, the corresponding narrow construction of priorities. ${ }^{126}$ At the outset of its opinion the majority explained that it refused to read ERISA's definition of the almost identical expression ("employee welfare benefit plan") into the "employee benefit plan" of the Bankruptcy Code because nothing in the Bankruptcy Code authorized the Court to do so. ${ }^{127}$ Since Congress

Howard Delivery, 126 S. Ct. at 2109, n.1.

${ }^{123}$ See Howard Delivery, $126 \mathrm{~S}$. Ct. at 2111 (stating $\S 507(\mathrm{a})(5)$ was provided to include benefits at issue in Embassy Rest. and Joint Industry and citing H.R. Rep. No. 95-595, at. 187 (1977), U.S. Code Cong. \& Admin. News 1978, pp. 5963, 6147-48, summarizing as "explaining that the amendment covers 'health insurance programs, life insurance plans, pension funds, and all other forms of employee compensation that [are] not in the form of wages"'); see also United States v. Embassy Rest., Inc., 358 U.S. 29, 33 (1959) (holding employer contributions to union welfare fund were not "wages due to workmen" thus not entitled to same priority status as wages); Joint Indus. Bd. of Elec. Indus. v. United States, 391 U.S. 224, 228 (1968) (determining employer unpaid contributions to annuity plan were not wages due to workmen, and stating it was more appropriate for Congress to overrule interpretation of statutory wage priorities in Embassy Rest).

${ }^{124}$ See 11 U.S.C. $\$ 507(a)(5)$ (2006); Howard Delivery, 126 S. Ct. at 2111 ("Congress created a new priority for [fringe] benefits, one step lower than the wage priority [under $\S 507(\mathrm{a})(4)] \ldots$. [allowing] the provider of an employee benefit plan to recover unpaid premiums"); see also S. REP. No. 95-989, at 59 (1978) (explaining section 507(a)(5) created "new priority for consumer creditor-those who have deposited money in connection with ... purchase of services . . that were not delivered or provided").

125 Howard Delivery, $126 \mathrm{~S}$. Ct. at 2111 .

${ }^{126} \mathrm{Id}$. at $2112-13,2116$ (noting federal court question "whether ERISA is appropriately used to fill in blanks in a Bankruptcy Code provision," recognizing workers' compensation provides both fixed payments for employees' on-the-job injuries and protects employers from significant tort liability, and using "corollary principle that provisions allowing preferences must be tightly construed" in applying the Code); Nathanson v. NLRB, 344 U.S. 25, 29 (1952) (determining, under Bankruptcy Act, "if one claimant is to be preferred over others, the purpose should be clear from the statute"); 4 COLLIER ON BANKRUPTCY, II 507.01, at 50710 (Alan N. Resnick et al. eds., 15th ed. rev. 2006) ("Because priorities grant special rights to the holders of priority claims, priorities under the Code are to be narrowly construed. A party must fit clearly within the requirements of the priority statute to be accorded priority status.").

${ }^{127}$ Howard Delivery, 126 S. Ct. at 2107 ("'Here and there in the Bankruptcy Code Congress has included specific directions that establish the significance for bankruptcy law of a term used elsewhere in the federal statutes.' No such directions are contained in $\$ 507(\mathrm{a})(5)$, and we have no warrant to write them into the text." (quoting United States v. Reorganized CF \& I Fabricators of Utah, Inc., 518 U.S. 213, 219-220 (1996)) (citations omitted)). 
had cross-referenced a few Bankruptcy Code sections to other statutes, ${ }^{128}$ the majority inferred that the lack of a cross-reference to ERISA in section 507(a)(5) disabled the Court from doing so of its own accord. ${ }^{129}$

The majority next compared workers' compensation to the types of employee benefits at issue in Joint Indus. Bd. and Embassy Rest. Unlike payments to union welfare funds and retirement annuities that benefit employees with no concomitant gain to employers, "[w]orkers' compensation regimes . . . provide something for employees - they assure limited fixed payments for on-the-job injuries-and something for employers-they remove the risk of large judgments and heavy cost generated by tort litigation." ${ }^{130}$ The six members of the majority also made much of the nearly universally compulsory nature of workers' compensation insurance. ${ }^{131}$ While acknowledging that not all states mandate that employers purchase workers' compensation insurance, the majority asserted that the largely compulsory nature of workers' compensation distinguished commitments to employee benefit plans, which benefit from bankruptcy priority, from run of the mill insurance obligations, which do not. ${ }^{132}$ Finally, the majority noted that granting priority status to an insurer like Zurich would have the anomalous effect of preferring debts to a private insurance carrier over general obligations such as taxes owing to a state. Without committing themselves, the majority strongly suggested that debts owed by employers to a state workers' compensation fund would enjoy only the standard

${ }^{128}$ See, e.g., United States v. Reorganized CF \& I Fabricators of Utah, Inc., 518 U.S. 213, 219 (1996) (noting some provisions in Bankruptcy Code deal with subjects identified outside Code or adopt definitions from other statutes, such as "places where the Bankruptcy Code makes referential use of the Internal Revenue Code"); City of New York v. Feiring, 313 U.S. 283, 284, 288 (1941) (finding seller obligation under New York City sales tax was consistent with "tax" entitled to priority payment under $\S 64$ of Bankruptcy Act); United States v. Sotelo, 436 U.S. 268, 275 (1978) (refusing to find cross reference "penalty" under Internal Revenue Code determinative of debtor's status under Bankruptcy Act).

${ }^{129}$ Howard Delivery, 126 S. Ct. at 2113 (noting Congress did not include directions construing section 507(a)(5) terminology, therefore, Court may not write them into text.).

${ }^{130}$ Id. Basic economics teaches that one party to commercial transaction would not benefit another without something in return: "Providing health care to workers fosters a healthy and happy workforce, and a contented workforce benefits employers." Id. at 2114, n.6. So the majority distinguished traditional employee welfare payments from workers' compensation benefits by asserting they were of a different "order:"

[T] he benefit employers gain from providing health and pension plans for their employees is of a secondary order .... These benefits redound to the employer reflexively, as a consequence of the benefit to the employee. Workers' compensation insurance, by contrast, directly benefits insured employers by eliminating their tort liability for workplace accidents.

Id.

131 See id. at 2114 ("Further distancing workers' compensation arrangements from bargained-for or voluntarily accorded fringe benefits, nearly all States, with limited exceptions, require employers to participate in their workers' compensation systems.").

${ }^{132}$ Id. ("We simply count it [mandated participation in workers' compensation systems] a factor relevant to our assessment that States overwhelmingly prescribe and regulate insurance coverage for on-the-job accidents, while commonly leaving pension, health, and life insurance plans to private ordering."). 
eighth level priority for unsecured claims of governmental units, three levels below the priority for obligations to employee benefit plans. ${ }^{133}$

Only after canvassing the standard tools of statutory construction did the majority cite two of the long-standing policies adduced to support its narrow construction of priority provisions. "[W]e are guided in reaching our decision," according to the Justice Ginsburg, "by the equal distribution objective underlying the Bankruptcy Code, and the corollary principle that provisions allowing preferences must be tightly construed." ${ }^{134}$ As it had in Joint Indus. Bd., the majority justified narrow construction of priorities out of a pragmatic concern for general unsecured creditors. Every dollar that goes to higher priority creditors would diminish the funds available for those of a lower priority. ${ }^{135}$ And, as it had in both Embassy Rest. and Joint Indus. Bd., the Court mentioned the anti-dilution argument and expressed apprehension that expanding the scope of the priority would redound to the detriment of employees whose direct section 507(a)(5) fringe benefits could be reduced by the indirect benefits of workers' compensation premiums. ${ }^{136}$

The majority did not, however, mention the fundamental and longstanding normative principle it had first stated in Guarantee Title and employed in both Joint Indus. Bd. and Embassy Rest.: concern for prompt alleviation of the economic distress suffered by workers and their families occasioned by employer insolvency. ${ }^{137}$ The Court nowhere explained why this argument had lost its cogency. Perhaps the presence of widespread and more generous unemployment

${ }^{133}$ Id. at 2115 ("We venture only this observation: It is common for Congress to prefer Government creditors over private creditors [citation omitted]; it would be anomalous, however, to advance Zurich's claim to level (a)(5) while leaving state-fund creditors at level (a)(8).") (citing New Neighborhoods, Inc. v. West Virginia Workers' Comp. Fund, 886 F.2d 714 (4th Cir. 1989)). The majority's opinion failed to note that to hold otherwise would have been inconsistent with its decision in Guarantee Title \& Trust Co. v. Title Guar. \& Sur. Co., 224 U.S. 152 (1912). In Guarantee Title the Court had concluded that the priority granted to wages over federal taxes under the 1898 Act implicitly modified the long-standing Federal Priority Statute of 1797. To grant a private creditor's claim for premiums that would otherwise have been paid to a state a priority equal to wages would subvert the policy of the wage priority:

The policy which dictated it [the priority of wages over taxes in the 1898 Act] was beneficent and might well induce a postponement of the claims, even of the sovereign, in favor of those who necessarily depended upon their daily labor. And to give such claims priority could in no case seriously affect the sovereign. To deny them priority would in all cases seriously affect the claimants.

Guaranty Title, 224 U.S. at 160.

${ }^{134}$ Howard Delivery, $126 \mathrm{~S}$. Ct. at 2116 (rejecting Zurich's argument that giving claim section 507(a)(5) status would incentivize workers' compensation carriers to continue coverage of failing enterprise, thus rehabilitating the business).

${ }^{135}$ See id. at 2116: ("Every claim granted priority status reduces the funds available to general unsecured creditors and may diminish the recovery of other claimants qualifying for equal or lesser priorities."); supra text accompanying notes 97-98.

${ }^{136}$ See Howard Delivery, $126 \mathrm{~S}$. Ct. at 2116 ("Opening the (a)(5) priority to workers' compensation carriers could shrink the amount available to cover unpaid contributions to plans paradigmatically qualifying as wage surrogates ...."); supra text accompanying notes 131-132.

${ }^{137}$ See supra text accompanying notes $91-94$. 
benefits lessened this concern. Or, perhaps observation of the glacial pace of many corporate reorganizations undercut the connection between priority and timeliness of relief. Or perhaps the shift from concern for family integrity to advocacy of individual autonomy occasioned the elision of this principle from the Court's set of important policies. ${ }^{138}$ In any event, the majority concluded by reiterating the equality principle and restating the argument it had made forty years earlier in Joint Indus. Bd. that it was for Congress to specifically provide for deviations from those policies.

Any doubt concerning the appropriate characterization [of unpaid workers' compensation insurance premiums], we conclude, is best resolved in accord with the Bankruptcy Code's equal distribution aim. We therefore reject the expanded interpretation Zurich invites. Unless and until Congress otherwise directs, we hold that carriers' claims for unpaid workers' compensation premiums remain outside the priority allowed by $\S 507(\mathrm{a})(5){ }^{139}$

\section{EFFICIENCY, AUTONOMY, OR JUSTICE?}

\section{A. Employees as Maladjusting Creditors}

A number of bankruptcy scholars have argued that the impact of consensual secured credit on priority should be limited where third parties do not have the capacity to adjust their prices or credit terms. ${ }^{140}$ Tort claimants are the archetypal examples of non-adjusting creditors. ${ }^{141}$ And employees are frequently cited as

${ }^{138}$ The Court's turn from a family-based understanding of privacy to one that that is characterized by virtually untrammeled individual autonomy is chronicled in David $\mathrm{M}$. Wagner, The Constitution and Covenant Marriage Legislation: Rumors of a Constitutional Right to Divorce Have Been Greatly Exaggerated, 12 REGENT U. L. REV. 53, 53 (1999-2000) (anticipating "constitutional attacks on covenant marriage legislation based on modern substantive due process"). See Larry Peterman \& Tiffany Jones, Defending Family Privacy, 5 J.L. \& FAM. STUD. 71, 72-73 (2003) ("[F]amily-based conception of privacy has increasingly given way to the idea that privacy attaches to individuals regardless of their family role."); John Tuskey, What's a Lower Court to Do? Limiting Lawrence v. Texas and the Right to Sexual Autonomy, 21 TOURO L. REV. 597 (2005-2006) (arguing Lawrence v. Texas holding is fact-sensitive and applies only to the instant case).

${ }^{139}$ Howard Delivery Serv., Inc. v. Zurich Am. Ins. Co., 126 S. Ct. 2105, 2116 (2006).

${ }^{140}$ See, e.g., Barry E. Adler, Financial and Political Theories of American Corporate Bankruptcy, 45 STAN. L. REV. 311, 340 (1993) ("Ideally, nonconsensual creditors would have the highest priority in any sort of firm."); Thomas H. Jackson, Bankruptcy, Non-Bankruptcy Entitlements, and the Creditors' Bargain, 91 YALE L.J. 857, 902-3 (1982) ("[N]on-consensual claimants, such as tort creditors, pose special problems to which application of a consensual model seems largely inapplicable."); Mark J. Roe, Commentary on "On the Nature of Bankruptcy": Bankruptcy, Priority, and Economics, 75 VA. L. REV. 219, 227 ("A rule of priority for nonbargain creditors seems efficient.").

${ }^{141}$ See supra text accompanying note 140; see also Lynn M. LoPucki, The Unsecured Creditor's Bargain, 80 VA. L. REV. 1887, 1908 (1994) ("[S]everal scholars writing on the puzzle of secured debt have acknowledged the plausibility of the arguments [that involuntary tort creditors should have priority over secured creditors] . . . ."); Christopher M.E. Painter, Tort Creditor Priority in the Secured Credit System: Asbestos Times, the Worst of Times, 36 STAN. L. REV. 1045, 1054-55 (1984) (discussing unfairness of 
another instance of non-adjusting creditors. ${ }^{142}$ But unlike tort victims, employees voluntarily choose their employer and assent to the terms of the employment relationship. Indeed, as Elizabeth Warren and Jay Westbrook have recently noted, in theory "[e]mployees can protect themselves from the risk of their employer's insolvency by investigating the company's financial condition and either seeking employment elsewhere or demanding higher wages to reflect the risk ...." ${ }^{143}$ They quickly go on, however, to make the following three points in arguing for the practical inability of employees to adjust their services in light of the financial condition of their employers:

The substantial sophistication and the high transaction costs required to obtain the necessary information present significant barriers. Moreover, the costs of moving from one employer to another can be quite onerous ... . Similarly, although most creditors have the option of spreading their risks by extending credit to several customers, this option is not available to employees, who are unlikely to work for more than a single employer. ${ }^{144}$

including "nonconsenting tort claimants in consent-oriented framework" of secured credit despite inability of tort claimants to adjust claims).

${ }^{142}$ See Lucian Arye Bebchuk \& Jesse M. Fried, supra note 70, at 885

We have just seen that involuntary creditors are not able to adjust the size of their claims when a borrower creates a security interest in favor of another creditor because their claims are fixed by law. But the fact that a creditor voluntarily contracts with a firm does not necessarily make that creditor adjusting with respect to any security interest created by the firm. Many of a firm's voluntary creditors are customers, employees, and trade creditors that have relatively small claims against the firm. Even though these creditors may sometimes, in principle, be able to take the existence of a security interest into account in contracting with the firm, the small size of their claims will generally make it irrational for them to do so.

Lynn M. LoPucki, Contract Bankruptcy: A Reply to Alan Schwartz, 109 YALE L.J. 317,337 (1999)

(citing employees as non-adjusting creditors); Eldon H. Reiley, Security Interests in Personal Property, 1 SEC. INTERESTS IN PERS. PROP. \$ 3:1 (Sept. 2007) (listing employees as non-adjusting creditors).

143 Elizabeth Warren \& Jay Lawrence Westbrook, Contracting Out of Bankruptcy: An Empirical Intervention, 118 HARV. L. REV. 1197, 1232 (2005).

${ }^{144}$ Id. 
Warren and Westbrook characterize employees as "maladjusting" creditors. ${ }^{145}$ While they have the potential to adjust their prices or places of employment, employees cannot effectively do so. Since 1887 the courts have acknowledged this perspective when construing the wage priority. ${ }^{146}$ Yet its cogency is questionable. Why should the law protect employees who fail to adjust by moving from a financially weak employer to one that appears more solvent? Or who fail to bargain for security or an increase in compensation to account for the risk of nonpayment? Doesn't the wage priority create a moral hazard?

Recognizing the weakness of Warren and Westbrook's analysis, Lucian Bebchuk and Jesse M. Fried take a slightly different route to arrive at the same destination. They do not argue that employees cannot adjust, but instead believe that it would be irrational for them to do so: "Many of a firm's voluntary creditors are . . . employees .... Even though these creditors can, in principle, take the existence of a security interest into account in contracting with the firm, the small size of their claims will generally make it rational for them not to do so."147 Simply put, the costs of calibrating the price of employment services to the potential value of unencumbered assets in the event of bankruptcy outweigh the benefit. It is thus irrational for individual employees to adjust. But Bebchuk and Fried do not address whether the employment market as a whole has adjusted for the possibility of nonpayment of wages when a firm enters bankruptcy. It may be the case that a portion of market-driven wages includes an "insolvency premium" to insure against the risk of nonpayment.

Because Warren and Westbrook believe that the labor market regularly fails employees on its own terms, they conclude that non-market intervention is necessary. The particular form of non-market intervention for their purposes is retention of a "mandatory" Bankruptcy Code in lieu of various suggested "contractual" insolvency alternatives that they describe in their article. ${ }^{18}$ Thus,

${ }^{145}$ Id. ("Employees in these circumstances might fairly be described as maladjusting creditors."). Warren and Westbrook do not clearly define "these circumstances." Are the concerns they raise about the practical ability of employees to adjust the price of their services (or take their services elsewhere) characteristic of all employees or only a subset? Intuitively there would seem to be many individual employees who can and do adjust prices in light of their employer's financial condition. See id. at 1239; 11 U.S.C. § 502(c)(2) (2006) (limiting administrative expense priority for certain severance payments to "key employees"). In fact, later in their article Warren and Westbrook admit as much: "We recognize that some of the creditors identified in these categories are only candidates for classification as maladjusting creditors; the information about them is too sketchy to permit a confident evaluation of their prebankruptcy readjustment capacities." Warren \& Westbrook, supra note 143, at 1238. See 11 U.S.C. $\$ 502(b)(7)$ (2006) (limiting administrative expense priority for certain severance payments to "key employees").

${ }_{146}$ See People v. Remington \& Sons, 10 N.Y.S. 310 (1887).

${ }^{147}$ Bebchuk \& Fried, supra note 70, at 885. Bebchuk and Fried conclude alternatives to full priority for secured credit should be examined with an eye toward protecting nonadjusting creditors like employees. See id. at 905-909 (discussing fixed-fraction priority, adjustable-priority, and consensual-priority as means of transferring value from secured to nonadjusting unsecured creditors).

${ }^{148}$ See Warren \& Westbrook, supra note 143 , at 1204 . Warren and Westbrook place contractualist solutions to corporate insolvency into one of three categories: automated bankruptcy (where priorities are built into a business's financial instruments), a menu system (where a prospective debtor chooses from among a limited set of statutory insolvency options in its organizing documents), and an evergreen regime 
while Warren and Westbrook do not address specifically the wage priority in section 507 of the Bankruptcy Code, we can reasonably assume that its presence is one of the non-market factors that they believe should be retained in any bankruptcy law. Bebchuk and Fried similarly do not address the wage priority. But one would hardly seem justified given their conclusion about the irrationality of employee evaluations of employer solvency. A wage priority would only reinforce the decision not to adjust, again creating a moral hazard.

\section{B. Employees as Autonomous Economic Actors}

It is by no means clear that economic arguments will resolve the wisdom of the wage priority provision. Perhaps wage earners can protect themselves through pricing their services, changing employers, or simply by staying put even with financially troubled firms if economically rational. Or, failing those alternatives, maybe they are sufficiently protected by the market generally, and do not need special priority protection in the Bankruptcy Code.

If only vindicating personal autonomy justifies coercive state action, Congress had little warrant for creating a priority for wage earners. The limitations on employee bargaining noted above hardly rise to the level of the incapacity typically associated with governmental paternalism. Employees are neither mentally nor physically disabled from acting rationally. Not all states offer employees a priority claim upon the insolvency of their employers; why should the federal government do so in bankruptcy? ${ }^{149}$ Nor are there any legal impediments to bargaining for security by employees. In fact, employees can have a strong bargaining position: "where the employer is attempting to reorganize in bankruptcy, the employees will almost always be crucial to the success of such an undertaking." 150

A hands-off policy toward wage priorities is consistent with classical liberal economic and political thought. And the Court's omission of reference to the needs of the employee's family is certainly consistent with the individualistic bent of autonomy-based theories of ethics.

(where the debtor and each creditor negotiate a contract for dealing with insolvency, the last of which is controlling on all). See id.

${ }^{149}$ See Paul G. Kauper, Insolvency Statues Preferring Wages Due Employees, 30 MICH. L. REV. 504, 50405 (1932) (discussing range of employee preference statutes during early years of Great Depression); Keating, supra note 4, at 926 ("[W]hy should a worker whose claim against its employer outside of bankruptcy is a general unsecured claim suddenly enjoy a preferred position merely by the happenstance of its employer filing for bankruptcy?").

${ }^{150}$ Keating, supra note 4, at 907 . Keating ultimately concludes that "[p]erhaps the best solution to the worker-priority issue is to eliminate the formal priorities and simply allow the workers to exercise what may be their best leverage anyway: their ability as valuable employees to affect whether or not their employer will prosper as a viable going-concern." Id. at 926. Some early New Jersey decisions remarked that the leverage of employees on foundering employers justified the state law preference. See, e.g., Lehigh Coal \& Navigation Co. v. Cent. R.R., 29 N.J. Eq. 252 (N.J. Ch. 1878); Bedford v. Newark Mach. Co., 16 N.J. Eq. 117 (N.J. Ch. 1863) 


\section{The Wage Priority as Justice}

Assuming that economic theory is inconclusive for the wage priority, is there anything else to support it? Do wage earners (and their families) deserve a priority for any reason other than their putative inability to adjust to an employer's relative solvency? What are we to make of the Court's obeisance to the principle of equality of distribution in light of the growing number of bankruptcy priorities? To address the wage priority from a normative point of view takes us back to its origins in the 1841 Act.

The 1841 Bankruptcy Act represents perhaps the earliest example of the confluence of evangelical Christian moralism and a nationalist political party with strong business ties. The direct ancestors of twenty-first century evangelicals came into being in the early nineteenth century. As David Bebbington has observed, evangelical Christianity was and is characterized by four distinctives: biblicism (a particular regard for the Bible as the sole source for moral living and ethics); crucicentrism (a focus on the atoning work of Christ on the cross over other aspects of the biblical description of Christ's work); conversionism (the belief that everyone, even professing Christians, need an experience of conversion, frequently with an emphasis on emotional suasion); and activism (the belief that the Christian Gospel needs to be expressed in serious efforts). ${ }^{151}$ George Marsden describes antebellum evangelicalism in similar terms with its emphasis on the free individual, education, technique, "back to the Bible" for answers to life's questions, and social reform. ${ }^{152}$ Bebbington's and Marsden's final distinctives of evangelicalism-activism and social reform-focusing on efforts by which the gospel was to be expressed, included the individual and the community. Evangelicals looked to reform the lives of individuals and the broader society in accord with their understanding of the Bible's moral strictures. Leading among the social expectations of ante-bellum evangelicals were temperance, ${ }^{153}$ slavery, ${ }^{154}$ and the rights of women. ${ }^{155}$ But the

${ }^{151}$ See D.W. BebBington, EvangeliCAlism In MODERn BRITAIN: A History From the 1730S to THE 1980s 2-3 (1988). For a discussion of evangelical social reform in America see GEORGE M. MARSDEN, RELIGION AND AMERICAN CULTURE 112 (1990).

Americans from the dominant classes were intensely moralistic, with a strong sense of civic responsibility. Civic responsibility and charity were, in fact, lessons that were always taught alongside the work ethic and tempered its individualism. . . . So reform in America often has a middle-class base, appealing to the Judeo-Christian principles that each person has responsibilities for the welfare of all their neighbors.

BEBBINGTON, supra at 2-3.

${ }^{152}$ MARSDEN, supra note 151 , at 53-63.

153 See HowE, supra note 22, at 543 ("The cause of temperance spread from its small-town religious origins to the cities."); Alfred L. Brophy, Harriet Beecher Stowe's Critique of Slave Law in Uncle Tom's Cabin, 12 J.L. \& RELIGION 457, 461 (1995-96) (noting evangelical reform of laws ranged from domestic relations to temperance); W.J. Rorabaugh, Note, Reexamining the Prohibition Amendment, 8 YALE J.L. \& HUMAN. 285, 288 (1996) (recognizing evangelical temperance movement began in 1820s and required abstinence for godliness and respectability). 
issues arising from the ballooning market-driven debtor-creditor relationship did not escape evangelicals' notice.

None of these four distinctives was unique to evangelical Christianity; however, evangelicalism's reduction of the scope of Christianity to only these four is significant. Two of these distinctives are particularly important for purposes of the relationship of ante-bellum evangelicals to politics. The first was evangelicalism's emphasis on social action. Many evangelicals were post-millennialists. ${ }^{156}$ That is, they believed that a reformation of the morality of American society would usher in Christ's millennial kingdom. ${ }^{157}$ Social progress was identified with the Kingdom of God and spurred by the belief that such progress was a condition precedent to the eschatological hope of the end of the present age and the arrival of the golden age to come. ${ }^{158}$ The second implication of evangelicalism's reductionism was its implicit

${ }^{154}$ See HowE, supra note 22, at 476; Alfred L. Brophy, Harriet Beecher Stowe's Critique of Slave Law in Uncle Tom's Cabin, 12 J.L. \& RELIGION 457, 461 (1995-96) (mentioning evangelical religious leader, Calvin Stowe, Harriet Beecher Stowe's husband, who developed comprehensive antislavery religious doctrine, "which asserted that slavery is inconsistent with Christ's teaching, demanded that human-made laws supporting slavery should be disobeyed, and claimed that slavery depressed the wages and quality of life of free workers"); Mark A. Sargent, The Coherence and Importance of Pro-Life Progressivism, 2 U. ST. THOMAS L.J. 384, 391 (2005) (recognizing anti-slavery movement was rooted in evangelical Christianity).

155 See, e.g., HOWE, supra note 22; SELLERS, supra note 22, at 54, 64 ("The reforms undertaken by the evangelicals of the time were typically concerned with redeeming persons who were not functioning as free moral agents: slaves, criminals, the insane, drunkards, children, and even-in the case of the most logically rigorous of the reformers-women."). The end of slavery in America was also distinctive among many Whigs. For an in-depth analysis of the intersection of evangelicals and the burgeoning market economy see NANCY A. HewitT, Women's ACTIVISM AND SOCial Change (1984). For a discussion of evangelicals and women's rights see NANCY A. HARDESTY, YOUR DAUGHTERS SHALl PROPHESY (1991).

${ }^{156}$ See George M. Thomas, Revivalism and Cultural Change: Christianity, Nation BuILDing, AND THE MARKeT IN THE NinETEENTH-CENTURY UNITED STATES 75-77 (1989); WallaCe G. Mills, MILlENNIAL ChRISTIANITY, BRIT. IMPERIALISM, AND AFR. NATIONALISM 337, available at http://huskyl.smu.ca/ wmills/course322/Millennial_Christianity.pdf (mentioning postmillennialism became dominant in Britain and North America in early nineteenth century); STEPHANIE STIDHAM RoGERS, AM. PROTESTANT PILGRIMAGE: NINETEENTH-CENTURY IMPRESSIONS OF PALESTINE 60, 63, available at http://65.209.121.29/koinonia/assets/issues/15/stidmanrogers2\%20--\%20for\%20web.pdf (explaining that postmillennialism was most widely accepted Protestant idea by middle of nineteenth century).

${ }^{157}$ See MARSDEN, supra note 151 , at 61

Millennial imagery had important implications for Americans at home as well. Americans regarded themselves, and were widely regarded, as "a city on the hill" for the advancement of civilization. They combined classic republicanism, Protestant dominance, and religious freedom into a belief that American civilization would be in the forefront of an outpouring of the Holy Spirit that would usher in the last millennial golden age of world civilization.

see also HowE, supra note 22, at 469 ("The spread of literacy, discoveries in science and technology, even a rising standard of living, could all be interpreted-and were-as evidences of the approach of Christ's Second Coming and the messianic age foretold by the prophets, near at hand."); Diana Hochstedt Butler, The Church and Am. Destiny: Evangelical Episcopalians and Voluntary Societies in Antebellum Am., 4 RELIGION AND AM. Culture 193 (1994) (obeying God's laws would begin to usher in millennium in their new world).

${ }^{158}$ See HowE, supra note 22 at 6 
depreciation of the place of the church as an institution. The explosion of in the number of American Christian denominations after the Founding era coupled with the rise of revivalism inevitably weakened the relationship of an individual Christian's relationship to a visible, institutional ecclesial body. With the reduction of the typical evangelical's identity to his or her personal relationship to Jesus, evangelicalism cut itself off from Christianity's historic form of collective social action in the church. Biblical metaphors for the Church, which the early Puritans had applied to their unique experiment in Massachusetts, were easily elided to the United States as a whole through the early nineteenth century. ${ }^{159}$ Christianity in America had become comfortable with the market's appeal to individual subjective value. ${ }^{160}$ Without the Church as the locus of holy living, society as a whole became the object of evangelicalism's activism. And what broader form of society was there than the nation?

Historian Edward Balleisen develops evangelicalism's moral activism regarding the debtor-creditor relationship in NAVIGATING FAILURE. ${ }^{161}$ Citing pamphleteers, writers of short stories, other texts, and sermons, Balleisen paints a picture in which both sides of the credit relationship bore moral responsibilities to the other and even to third parties. For debtors, the "guiding lights for a failing American were 'a fair

\begin{abstract}
American religion displayed remarkable originality. Millenarians warned of the imminent Second Coming of Christ. The evangelical movement prompted national soul-searching and arguments over the country's goals and the best means to achieve them. Reformers motivated by religion challenged long-held practices relating to the treatment of women, children, and convicts ....
\end{abstract}

Wallace G. Mills, MillenNial Christianity, BRIT. Imperialism, and AFr. Nationalism, 337, available at http://huskyl.smu.ca/ wmills/course322/Millennial_Christianity.pdf ("The Kingdom of God (the millennium) will be formed gradually through individual conversions and societal improvement."); Richard J. Carwardine, Lincoln, Evangelical Religion, and Am. Political Culture in the Era of the Civil War, 18 J. ABRAHAM LINCOLN ASS'N 27, 30 (1997) (recognizing evangelicals stressed public responsibilities of Christians would bring about glorious millennium).

${ }^{159}$ See Louis Weeks, God's Judgment, Christ's Command: Use of the Bible in Nineteenth-Century American Political Life, THE BIBLE IN AMERICAN LAW, POLITICS, AND POLITICAL RHETORIC 61, 62 (James Turner Johnson ed., Scholars Press 1985) (1985)

\begin{abstract}
Themes from the Bible, which had been applied to the church before being applied to the nation, continued to be popular throughout the century: "a city set upon a hill," "a light to the nations," "the servant of the Lord," "the chosen people," and "the mission of the nation" all made their way as expressions in the political life of the United States, still bearing biblical freight.
\end{abstract}

Daniel H. Levine, Religion and Politics in Comparative and Historical Perspective, 19 COMPARATIVE Politics 95, 120 (Oct. 1986) (discussing how Puritan contractual notions evolved into democratic forms in Catholicism today); Milette Shamir, "Our Jerusalem," 55.1 AM. Q. 29, 35 (2003) ("Americans were a people because they were like the "Chosen People"; they were entitled to their land because it was like the Biblical 'Promised Land.'"').

${ }^{160}$ See, e.g., MOORE, supra note 25 (arguing market revolution used evangelicalism). For a discussion of the relationship between social/economic change and religious movements in an earlier context see C. Scott Pryor, The Puritan Revolution and the Law of Contracts, 11 TEX. WESLEYAN L. REV. 291 (2005).

161 EDWARD J. BALleISEN, NAVIGATING FAILURE: BANKRUPTCY AND COMMERCIAL SOCIETY IN ANTEBELluM AMERICA 70 (Chapel Hill University of North Carolina Press 2001). 
disclosure, a full surrender, and an equal distribution."'162 Creditors were not immune from evangelicals' moral strictures:

[T] he holders of claims against insolvents ought to respect the rightful interests of other parties. Rather than seek an advantage over his neighbor, the creditor of a bankrupt should deem his honor of more value than even the preference of a large percentage of pecuniary gain. Other prescriptions emphasized the duty of charity toward those who had suffered misfortune. ${ }^{163}$

Even the concept of property as "despotic dominion" became the object of critical moral analysis. A purposeful understanding of property as a means of large-scale social improvement moved the question of what could count as property into the realm of theological discussion. ${ }^{164}$

The continuing moralization of all debt is significant. Bruce Mann has argued in REPUBLIC OF DEBTORS that the waning years of the eighteenth century reflected both a mindset of debt (particularly the failure to repay it) as sin as well as a grudging but increasing recognition that debt was necessary for a commercial society:

[T] he moral economy of debt had lost its religious underpinnings by the end of the eighteenth century, at least for commercial debtor. The redefinition of insolvency from moral failure to economic risk did not eliminate debtors' legal obligations to repay their debts. Rather, it secularized the foundations of the moral obligation to repay ... and changed the general understanding of how the law should treat failure. ${ }^{165}$

${ }^{162}$ Id. (quoting an 1839 address of Philadelphia merchant John Sargeant).

${ }^{163}$ Id. (internal quotation marks omitted).

164 See Gamester v. Massey, 158 N.E.2d 805, 807 (Ind. Ct. App. 1959) (defining "absolute" as "completely, wholly; without qualification"); Thomas D. Russell, A New Image of the Slave Auction: An Empirical Look at the Role of Law In Slave Sales and a Conceptual Reevaluation of Slave Property, 18 CARDOZO L. REV. 473, 492 (1996) (stating master's power over his property must be absolute); Max L. Stackhouse, Jesus and Economics: A Century of Reflection, in THE BIBLE IN AMERICAN LAW, POLITICS, AND POLITICAL RHETORIC 115 (James Turner Johnson ed., Scholars Press 1985) (1985)

[T] he roots of the American reexamination of economic ethics are in the revivals of the pre-Civil War period. The origins of "social Christianity" in its modern forms were distinctly influenced by the new burst of evangelicalism. This [late Eighteenth-Century] alliance [of Calvinism and the Enlightenment had] produced both new shapes of democratic constitutional government and an interpretation of private property that was nearly absolute. But in the ante-bellum revival movements, the absoluteness of property was challenged ....

${ }^{165}$ Mann, supra note 10, at 260. See Deborah A. Ballam, The Evolution of the Govermment-Business Relationship in the United States: Colonial Times to Present, 31 AM. BuS. L.J. 553, 561 (1994) (asserting sinful perception of not repaying debts); PETER J. COLEMAN, DebTORS AND CREDITORS IN AMERICA: 
Mann over-stated the secularizing influences of the burgeoning market economy. Notwithstanding an understanding of the commercial utility of debt that became widespread after the Founding era, both efficiency and morality continued to dominate the debates around the 1841 Act. Like the other moral causes of antebellum America-temperance, abolition of slavery, and women's rightsbankruptcy reformers cast their rhetoric in explicitly ethical terms. ${ }^{166}$ Policy-makers of the early nineteenth century did not observe the contemporary compartmentalization of utility and morality. Distinct arguments stressing one or the other ethical theory were made but both were seen as part of a divinely ordered natural system in which what was efficient was providentially designed to correspond to virtue. ${ }^{167}$ As Balleisen observes, "when the economic dislocations of the late 1830 s and early 1840 s created political pressures for revisions of debtorcreditor law, and especially for the adoption of a national bankruptcy system, the creed of 'the church commercial' guided the labors of congressional draftsmen."

INSOLVENCY, IMPRISONMENT FOR DEBT, AND BANKRUPTCY, 1607-1900 285 (The State Historical Society of Wisconsin 1974)

[T] he plunging, speculative, promoter type who came to typify the driving, high-risk segment of American business after the Revolution unwittingly contributed to the formation of attitudes essential to the acceptance of the discharge of debts. Initially the old morality prevailed. . . However, as the nineteenth century advanced more and more Americans became tolerant of and indeed attracted to speculative ventures. . . . And so the pendulum of opinion swung from hostility to bankruptcy relief to an attitude that mixed indifference with tolerance and outright approval.

166 See, e.g., BALLEISEN, supra note 161, at 165 ("In discussing the plight of bankrupts, commercial moralists and their political allies emulated the rhetorical strategies of most antebellum reform movements."); see JoEllen Lind, Symbols, Leaders, Practitioners: The First Women Professionals, 28 VAL. U. L. REV. 1327, 1335 (1994) (discussing reasons for rise of women's economical role during ante-bellum America); Reva B. Siegel, Home As Work: The First Woman's Rights Claims Concerning Wives' Household Labor, 1850-1880, 103 YALE L.J. 1073, 1111 (1994) (noting that antebellum America "produced an equal rights discourse that was confident of the value of women's work").

${ }^{167}$ See, e.g., WILliam PALEy, PRINCIPLES OF MORAL AND POLITICAL PHILOSOPHY 60-62 (PUBLISHER 1785) (arguing that observation of nature is principal "method of coming at the will of God" by which we can promote human happiness). Even though Paley was English, his work was one of the leading treatises on ethics in ante-bellum America. See HowE, supra note 22, at 465; see also Charles Jordan Tabb, The Scope of the Fresh Start In Bankruptcy: Collateral Conversions and the Dischargeability Debate, 59 GEO. WASH. L. REv. 56, 98 n.294 (1990) (discussing great moral debate regarding Bankruptcy Act of 1841); Richard C. Sauer, Bankruptcy Law and the Maturing of American Capitalism, 55 OHIO ST. L.J. 291, 327 (1994) (bringing down Congress' moral concerns in early 1940's). Even though Paley was English, his work was one of the leading treatises on ethics in ante-bellum America. See HOWE, supra note 22, at 465; see also Joseph M. Perillo, The Origins of the Objective Theory of Contract Formation and Interpretation, 69 FORDHAM L. REV. 427, 455 n.169 (2000) (lauding Paley for his popularity in early nineteenth century); FRANCIS WAYLAND, THE ElEMENTS OF MORAL SCIENCE 250 (1851). The first edition of Wayland's work was published in 1835 and was "the most widely used American textbook on moral philosophy." HOWE, supra note 22 , at 476 . 
The congressional draftsmen in 1840 were the Whigs. ${ }^{168}$ The Whig party was led by northern industrialists and western nationalists who had organized for the 1832 election and attempted to pull together all of the opposition the reelection of Andrew Jackson. ${ }^{169}$ As articulated by Daniel Walker Howe,

Whiggery stood for the triumph of the cosmopolitan and national over the provincial and local, of rational order over irrational spontaneity, of school-based learning over traditional folkway and customs, and of self-control over self-expression. Whigs believed that every person had the potential to become moral or good if family, school, and community nurtured the seed of goodness in his moral nature. ${ }^{170}$

${ }^{168}$ Daniel Webster was the principal draftsman of the 1841 Act. See Mark E. Steiner, Lawyers and Legal Change In Antebellum America: Learning From Lincoln, 74 U. DET. MERCY L. REV. 427, 432-33 (1997) (discussing Abraham Lincoln and Whig ideology); Paul E. McGreal, Unconstitutional Politics, 76 NOTRE DAME L. REV. 519, 607 (2001) (acknowledging that the Whigs took over Congress in 1840); David P. Currie, The Constitution In Congress: The Public Lands, 1829-1861, 70 U. CHI. L. REV. 783, 785 (2003) (noting that Whig dynasty was short lived: "Of the nine presidential elections from 1828 to 1860 , the Whigs won only two (in 1840 and 1848)"). Daniel Webster was the principal draftsman of the 1841 Act. See F. REGIS NOEL, A HISTORY OF THE BANKRUPTCY LAW 138 (1919) ("The law of 1841 was largely the work of Daniel Webster . ...."). Webster took much of the Act, including the wage priority provision, from a recently enacted Massachusetts statute. See An Act for the Relief of Insolvent Debtors, and for the more equal distribution of their effects, ch. CLXII, § 24, 1838 Mass. Laws. For hints of Webster's connection with evangelicalism see DANIEl WalKer Howe, THE POLITICAL CulTuRE OF THE AMERICAN WHIGS 18 (1979) ("Whig political leaders like Henry Clay and Daniel Webster cultivated good public and private relations with clerical opinion-makers."). But see id. at 222 ("Webster's own religious faith was bland, nontheological, and ecumenical."); ROBERT V. REMINI, DANIEL WEBSTER: THE MAN AND HIS TIME 87 (1997) (quoting Webster's orthodox confession of faith written in 1807 as condition of membership in Salisbury Congregational Church).

${ }_{169}$ See 1 SAmuel Eliot Morison \& Henry SteEle Commager, The GrowTh of THE AMERICAN REPUBLIC 485 (4th ed. 1950) (1930); John A. Eidsmoe, Warrior, Statesman, Jurist for the South: The Life, Legacy, and Law of Thomas Goode Jones, 5 JONES L. REV. 51, 60 (2001) ("The Whig party of the 1800's was an amalgamation of former Federalists, conservative factions of the Democratic-Republican Party, Southern cotton planters who opposed the leveling doctrines of Andrew Jackson and his followers, and industrialists who wanted the protection of high tariffs."); H. Jefferson Powell, Joseph Story's Commentaries on the Constitution: A Belated Review, 94 YALE L.J. 1285, 1300 (1985) ("[W]hen the nationalist opponents of Andrew Jackson organized, they reached even further back into America's republican heritage, and called themselves Whigs.").

${ }^{170}$ MORISON \& COMMAGER, supra note 169, at 485 (quoting LOUISE STEVENSON, SCHOLARLY MEANS TO EVANGELICAL ENDS: THE NEW HAVEN SCHOLARS AND THE TRANSFORMATION OF HIGHER LEARNING IN AMERICA, 1830-1890 5-6(1986)). 
While the sets of evangelicals and Whigs were by no means identical, ${ }^{171}$ there was a substantial overlap, especially in the North. ${ }^{172}$ Desire to reform society in terms of manners and decorum easily meshed with maintaining the Second Bank of the United States and protective tariffs to enhance a broadening market economy. ${ }^{173}$ The continuing effects of the Panic of 1837 through the depression of 1839 attracted the attention of evangelical preachers and Whig politicians. ${ }^{174}$ Various petitions to Congress about the bankruptcy legislation help establish the moralized context of Congressional action. ${ }^{175}$ A connection between evangelicalism and the Whig party

${ }^{171}$ In other words, evangelical leaders were not mere theological water carriers for the Whig business elites. See Stewart Allen Davenport, Moral Man, Immoral Economy: Protestant Reflections on Market Capitalism, 1820-1860, at 33 (2001) (unpublished Ph.D. dissertation, Yale University) (on file with author)

It is also important to point out ... . that all of the clerical economists, being the intellectual disciples of Adam Smith that they were, strongly supported free-trade: a position on national economic policy that was fundamentally at odds with the predominant Whig agenda of high-tariff protection for America's nascent industries.

William W. Fisher III, Ideology, Religion, and the Constitutional Protection of Private Property: 1760 1860, 39 EMORY L.J. 65, 109 (1990) (discussing interaction between Whig Party and evangelical Christians); Herbert Hovenkamp, Law and Morals in Classical Legal Thought, 82 IOWA L. REV. 1427, 1439 (1997) (mentioning split within evangelicals, some following Jacksonians rather than Whigs).

172 See HowE, supra note 22, at 573 ("[W]e know that the Whig Party appealed to many members of evangelical religious bodies."); Fisher, supra note 171, at 109 ("[T]he evangelicals helped mold-and thereafter lent their support to-the platform of the political party soon to assume the label 'Whig.'"); Hovenkamp, supra note 171 , at 1439 (stating many northern Baptists remained Whig loyalists rather than joining Jacksonians).

${ }_{173}$ See Memorial of Silas M. Stilwell and Others, CtTizens of New York, PRaying THE PASSAGE OF A GENERAL BANKRUPT LAW, S. DOC. NO. 26-154, at 4 (1st Sess. 1840) (pleading for congress to enact national economic plans, since "[t]he [current] laws compel a man to be dishonest"); Noll, supra note 24, at 12 (using "formalist/antiformalist" division within early American Protestantism, the author states that formalists generally felt a responsibility to use money for broad national projects). But see James Bovard, The Morality of Protectionism, 25 N.Y.U. J. INT'L L. \& POL. 235, 238 (1993) (discussing morality, or lack thereof, in protectionism).

${ }^{174}$ See HowE, supra note 22, at 579

\begin{abstract}
Indeed, evangelical preachers, like the Whig campaigners, had been calling attention to the depression. The preachers saw it as a divine punishment visited upon the people for their sins both individual and collective, including cupidity, fraud, violations of the Sabbath, and injustice to the Indians .... [Whig presidential candidate William Henry] Harrison specifically courted evangelical voters with assurances of his sabbatarian, Anti-masonic, and temperance principles.
\end{abstract}

Daniel W. Levy, A Legal History of Irrational Exuberance, 48 CASE W. RES. L. REV. 799, 825-26 (1998) (discussing relation of 1837 crisis to comprehensive bankruptcy scheme, protective tariffs, and distribution of public lands that Whigs made part of their electoral platform); John M. Czarnetzky, The Individual and Failure: A Theory of the Bankruptcy Discharge, 32 ARIZ. ST. L.J. 393, 427-28 (2000) (describing effect of 1837 crisis on politics and eventual adoption of bankruptcy laws by Whig government).

175 See, e.g., MEMORIAL OF A NUMBER OF CITIZENS OF NEW YoRK, REMONSTRATING AgAINST THE PASSAGE OF A RETROSPECTIVE BANKRUPT LAW, S. DOC. No. 27-36 (1st Sess. 1841) (praying Congress not assist those who were not too ambitious to be content with regular comforts of life); MEMORIAL OF A Number of Citizens of New YoRk, REMONSTRATing Against THE Passage of a ReTROSPECTIVE BANKRUPT LAW, S. DOC. No. 27-35 (arguing against passage of bankruptcy bill "that threatens to prostrate 
is undeniable and is an interesting precursor of the contemporary relationship of evangelicals and the Republican Party. ${ }^{176}$ Religious motivations for voluntary bankruptcy in general would certainly have trickled down the wage priority in particular.

With no success against Andrew Jackson or against Jackson's successor Martin Van Buren in 1836, the Whigs by 1840 found themselves with a real prospect of victory due to the lingering effects of the Panic of 1837 . The decades preceding the election of 1840 had seen many states eliminating requirements for the franchise such as property ownership. ${ }^{177}$ Given the increasing number of persons entitled to vote, especially in the industrialized North, ${ }^{178}$ the Whigs needed to broaden their appeal to the newly enfranchised: "It was necessary to out-demagogue the Democrats. ${ }^{179}$ And one of the Whigs' means of reaching the non-elite masses was to capitalize on the continuing depression ${ }^{180}$ and support bankruptcy legislation. ${ }^{181}$ The Whigs swept to victory with the election of William Henry Harrison and took control of Congress. And the support of evangelicals for the Whigs was crucial. ${ }^{182}$ Keeping their promise, "the Whig-dominated $27^{\text {th }}$ Congress again created a federal bankruptcy system, largely in the hope of attracting the political support of thousands of American whose businesses had failed ...." ${ }^{183}$ The breadth of who

both the credit and the integrity of all classes"); Memorial of Silas M. Stilwell, supra note 173, at 2-5 (stressing need for comprehensive bankruptcy law to promote honesty in dealings).

${ }^{176}$ See HOWE, supra note 22 , at 9

\begin{abstract}
Whig political culture was profoundly influenced by the Second Great Awakening, an outburst of evangelical activity which ... sought to transform society along moral lines. For the religious crusaders who led the temperance, peace, antislavery, missionary, and other benevolent societies, it was not enough to win individual souls to Christ; society as a whole must respond to His call. American Whigs, many of them members of the evangelical sects, typically believed in the collective redemption of society....
\end{abstract}

James W. Gordon, Religion and the First Justice Harlan: A Case Study in Late Nineteenth Century Presbyterian Constitutionalism, 85 MARQ. L. REV. 317, 355 (2001) (describing new Republican party created from rift in Whig party over slavery expansion as "marriage" of secular politics and evangelical morality). See generally Sean Wilentz, Bush's Ancestors, N.Y. TIMES, Oct. 16, 2005 (tracing history of current-day Republican Party from Whig/Christian evangelical start to conservative air that attaches to the party today).

${ }^{17}$ See HowE, supra note 22, at 489 ("During the years after 1815, state after state abolished property requirements for voting ....").

${ }^{178}$ See id. at 489-90.

${ }^{179}$ MORISON \& COMMAGER, supra note 169, at 555.

180 See HowE, supra note 22, at 506 ("The depression [of 1839] gave the Whig Party a new lease on life.").

181 See BALLEISEN, supra note 161, at 104 ("[A]s the presidential election of 1840 approached, Whig leaders seized on bankruptcy reform as a leading issue for their campaign.").

${ }^{182}$ See HOWE, supra note 22, at 580 ("Supporters and opponents of evangelical revivalism generally lined up on opposite sides of the Whig-Democratic political debate ... . The Whig party benefited from evangelicals who decided to enlist the power of the state on behalf of reform.").

183 BAlleISEN, supra note 161, at 102. See DAVID A. SKEEL, JR., DEBT's DOMINION: A HISTORY OF BANKRUPTCY LAW IN AMERICA 31 (2001) ("The 1841 act was the brainchild of the Whig party, which had made bankruptcy law a crucial plank of the platform that brought them the presidency and control of the Senate the year before."). 
could be a debtor and the ability to seek voluntary bankruptcy relief confirmed the Whigs' intent to retain the support of the many who suffered greatly from the continuing economic depression. ${ }^{184}$

Creation of the wage priority was consistent with the Whigs' rent-seeking program for continuing electoral success. The wage priority also harmonized with the family-centered moralism of ante-bellum evangelicals. ${ }^{185}$ As Balleisen observes in connection with debtor obligations under the 1841 Act,

Drawn from the suggestions of bankruptcy reformers with ties to commercial moralism, these disciplinary elements [e.g., voidability of preferences] reflected a coercive impulse born of frustration with the impacts of moral suasion-much as calls for prohibition of alcohol grew out of impatience among temperance advocates with the results of mere agitation. ${ }^{186}$

When one remembers that the evangelical commercial moralists spoke to the ethical duties of creditors as well as debtors, it is reasonable to conclude that the wage priority also grew out of similar sympathies. Just as debtors had a moral obligation to pay, so creditors had a moral obligation to extend mercy. The former had long received legal sanction; the latter was about to find its way into the law as well. Even the epithet attached to the 1841 Act by its opponents-"Jubilee of the Bankrupts"-pays homage to the biblical perspective in which the new law was considered. ${ }^{187}$ If the 1841 Act as a whole was perceived in terms of the release laws recorded in Leviticus 25, it is likely that a biblically literate population saw the

\footnotetext{
184 See supra text accompanying note 33; see also BALLEISEN, supra note 161, at 102 ("To curry favor with these voters, the Whigs made bankruptcy discharges available to all citizens and allowed debtors as well as creditors to initiate bankruptcy proceedings.").

${ }^{185}$ See BALLEISEN, supra note 161, at 104 ("Taking their cue from both the commercial moralists and the fervent demands of bankrupts, Whig leaders cobbled together a bill that gave all Americans the ability to petition for bankruptcy relief.").

${ }^{186} \mathrm{Id}$. at 102 .

${ }^{187}$ Id. at 132
}

\begin{abstract}
"Jubilee of the Bankrupts"-so one critic had derisively termed the 1841 Federal Bankruptcy Act, and in hindsight, with considerable justification. In light of the legislation's expeditious repeal, there is a strong temptation to deem it an ephemeral showering of legal releases upon one generation of ruined proprietors, very much akin to a biblical cancellation of debts.
\end{abstract}

The reference to "jubilee" is taken from Leviticus 25 where the Torah provided that every 50 years the Israelites were to be freed from debt servitude and restored to their ancestral lands. See William Baur, Jubilee Year, International Standard Bible Encyclopedia, http://www.biblehistory.com/isbe/J/JUBILEE+YEAR/ (last visited February 12, 2008); see also, John Fabian Witt, Narrating Bankruptcy/Narrating Risk, 98 NW. U. L. REV. 303, 332 (2003) ("Critics of bankruptcy feared that legislation like that enacted in 1841 would instigate a 'Jubilee of the Bankrupts'-debtors would rush pellmell into the federal courthouses to be released from their obligations."). 
wage priority in terms of passages such as Leviticus 19:13, ${ }^{188}$ Deuteronomy $24: 15,{ }^{189}$ and James $5: 4,{ }^{190}$ each of which clearly enjoined the prompt payment of wages. ${ }^{191}$ Other than payment of vows made to God, no specific financial obligation received such frequent biblical mention as the duty to pay wages to workers. The continuing moralization of the debtor-creditor relationship by ante-bellum commercial moralists, consistent with a plain reading of the $\mathrm{Bible}^{192}$ in the context of a market economy with a rising class of wage earners, carries considerable weight in understanding the moral calculus of the wage priority of the 1841 Act. And the references in judicial opinions prior to the Zurich American decision to the particular needs of wage-earners and their families over the course of more than a century suggest a continuing recognition of a normative moral principle underlying the wage priority.

\section{CONCLUSION}

Neither the majority nor the dissent in the Zurich American opinion referred to the principle of protection of employees and their families by prompt payment of wages that had animated previous decisions in this field. The dissent's reticence is

${ }^{188}$ See Leviticus 19:13 (King James) ("Thou shalt not defraud thy neighbour, neither rob him: the wages of him that is hired shall not abide with thee all night until the morning.") All biblical quotes are from the Authorized (King James) Version, the single translation commonly in use in nineteenth-century America.

${ }^{189}$ See Deuteronomy 24:15 (King James) ("At his day thou shalt give him his hire, neither shall the sun go down upon it; for he is poor, and setteth his heart upon it: lest he cry against thee unto the LORD, and it be sin unto thee.").

${ }^{190}$ See James 5:4 (King James) ("Behold, the hire of the labourers who have reaped down your fields, which is of you kept back by fraud, crieth: and the cries of them which have reaped are entered into the ears of the Lord of sabaoth."); WAYLAND, supra note 167, at 250 (quoting this passage in the context of directly applicable contemporary morality).

991 See HowE, supra note 22 , at 3 ("[B]iblical religion then permeated the culture in ways both conventional and sincerely felt.").

${ }^{192}$ See HowE, supra note 22 , at 447

The Reformation principle of sola scriptura that the Bible contained all things necessary for salvation and could be properly interpreted by any conscientious believer, lived on and heavily influenced American culture. . . . Respect for the Bible conditioned national identity, social criticism, natural science, the educational system, and the interpretation of authoritative texts like the Constitution.

Mark A. Noll, The Image of the United States as a Biblical Nation, 1776-1865, in THE BIBLE IN AMERICA: ESSAYS IN CULTURAL HISTORY 51 (New York: Oxford University Press 1982)

In the years between the American Revolution and the Civil War, the Bible offered to many Americans a key for understanding not only private religious reality but also the public life of the country. The Scriptures were so widely used that it is not inaccurate to call the country a biblical nation during this period.

HowE, supra note 22, at 475 ("The Bible occupied an even more prominent position in discussions of morality than it did in education and science. Pre-Civil War Americans debating moral issues almost always appealed to biblical authority."). 
understandable: There is little reason to conclude that a policy of protecting workers from the vicissitudes of sudden unemployment would buttress awarding a priority for workers compensation insurance. Workers compensation insurance itself is consistent with the normative perspective of special protection for wage earners. Yet priority for the premiums due from employers seems too indirect to draw the same endorsement, especially when such a priority would dilute a state's lower priority for taxes levied for the same benefit. If neither of the forms of employee benefits addressed in Embassy Rest. (contributions to union welfare fund) or Joint Indus. $B d$. (contributions to employee's annuity plan) fell within the policy of the wage priority, the more attenuated nature of workers compensation could scarcely do so.

It is harder to understand the majority's silence. The Court's precedents had confirmed the purpose of the wage priority as a means by which employees and their families could get their daily bread. Each of the preceding six-member majorities had also established the corollary that deferred employee benefits did not fall within wage priority. Congress added section 507(a)(4) in 1978 only after concluding that fringe benefits had frequently come to substitute for wages over the course of the twentieth century. To be sure, employee benefits now enjoy a priority but that extended priority did not arise from the moral milieu of the original wage priority. Employee benefit plans did not have the same nexus to survival as did the prompt payment of wages. And neither commercial moralists nor evangelical activists played a role in sculpting the benefits priority. It is thus not surprising that the majority balked at expanding the reach of employee benefits priority. It is surprising that the opinion failed to acknowledge its consistency with a trajectory beginning over 160 years earlier and regularly confirmed thereafter.

The policy of the wage priority is firmly grounded in the physical needs of workers and their families. The justification of the wage priority certainly includes this policy but its early history suggests there was more to it than simple benevolence. The transformative moral vision of ante-bellum American evangelicals believed in a foundation for that policy in a biblical-theological understanding of the calling of the United States as God's tool of universal reconciliation. Combined with the political calculations of the Whig party, theology influenced law. Additionally, the existence of the wage priority suggests a more full-orbed view of evangelical social action than is generally credited by contemporary evangelicals or their opponents. The durability of the wage priority suggests that at least some theological perspectives can be effectively translated into broadly acceptable social policies through conversion to public reasons, a truth that can inform contemporary debates on many issues. 